RUNNING HEAD: Lucid dream induction review

\title{
Induction of lucid dreams: A systematic review of evidence
}

\author{
Tadas Stumbrys \\ Heidelberg University, Germany \\ Daniel Erlacher \\ University of Bern, Switzerland \\ Melanie Schädlich \\ University of Bonn, Germany \\ Michael Schredl \\ Central Institute of Mental Health, Mannheim, Germany
}

Author Note

Correspondence concerning this article should be addressed to Tadas Stumbrys, Heidelberg

University, Institute of Sport and Sport Science, Im Neuenheimer Feld 700, 69120

Heidelberg, Germany.

Email: tadas.stumbrys@issw.uni-heidelberg.de 


\begin{abstract}
In lucid dreams the dreamer is aware of dreaming and often able to influence the ongoing dream content. Lucid dreaming is a learnable skill and a variety of techniques is suggested for lucid dreaming induction. This systematic review evaluated the evidence for the effectiveness of induction techniques. A comprehensive literature search was carried out in biomedical databases and specific resources. Thirty-five studies were included in the analysis (11 sleep laboratory and 24 field studies), of which 26 employed cognitive techniques, 11 external stimulation and one drug application. The methodological quality of the included studies was relatively low. None of the induction techniques were verified to induce lucid dreams reliably and consistently, although some of them look promising. On the basis of the reviewed studies, a taxonomy of lucid dream induction methods is presented. Several methodological issues pertaining to both studies reviewed and lucid dream induction research in general are discussed.
\end{abstract}

Key words: lucid dreaming; induction techniques; systematic review; classification 
Induction of lucid dreams: A systematic review of evidence

\section{Introduction}

\subsection{Lucid dreams}

A lucid dream is a dream during which the dreamer is aware of the fact that he or she is dreaming and therefore often can consciously influence the dream content (LaBerge, 1985). Although awareness of dreaming while dreaming is usually considered an adequate criterion for lucid dreaming, some discussions have been held whether this is sufficient (Gillespie, 1984; Tart, 1984, 1985). Tart (1984), for example, separates dreaming-awareness-dreams and lucid dreams, for which he poses an additional criterion that overall clarity of waking consciousness should also be retained. Tholey (1985) describes seven aspects of lucidity (clarity): (1) clarity about the state of consciousness (that one is dreaming); (2) clarity about the freedom of choice; (3) clarity of consciousness; (4) clarity about the waking life; (5) clarity of perception; (6) clarity about the meaning of the dream; (7) clarity recollecting the dream. According to him, (1) - (4) are indispensible prerequisites of lucid dreaming. While in this paper we will follow the conventional minimal criterion for the definition (awareness of dreaming while dreaming), it is important to acknowledge that dream lucidity is not an "allor-nothing” phenomenon but rather a continuum with different degrees: some dreams can be more lucid than others (Barrett, 1992; Moss, 1986).

Despite the fact that the phenomenon of lucid dreaming was known since the times of Aristotle (see Aristotle, trans. 2007), only thirty years ago it was successfully verified in a sleep laboratory by measuring eye movements during REM sleep corresponding with dreamed gaze shifts (Hearne, 1978; LaBerge, 1980a; LaBerge, Nagel, Dement, \& Zarcone, 1981). Since then, numerous studies have been conducted and research (overview: Erlacher \& Schredl, 2008a) indicates that lucid dreaming is mainly a REM sleep phenomenon. 
During REM dreams the skeletal muscles of the sleeping body are actively suppressed by neural structures in the brain stem, keeping dreamers from actually acting out actions in their dreams (Hobson, Pace-Schott, \& Stickgold, 2000). One obvious exception is eye movements. In accordance with the scanning hypothesis, eye movements during REM sleep correspond with shifts of gaze in dream imagery (cf. Roffwarg, Dement, Muzio, \& Fisher, 1962). Since lucid dreamers have access to their waking memories (cf. Erlacher, 2009), it is possible for them to move their eyes during the dream according to a prearranged pattern of eye movements (usually: left-right-left-right, LRLR) and produce a distinct electrooculagram (EOG) recording during REM sleep; i.e, they can communicate from within the dream (cf. LaBerge et al, 1981). Then the lucid dreamer can be awakened and asked for a dream report to match the recorded eye signals with the dreamed gaze shifts. In such way, REM lucid dreams were successfully verified by subjective dream reports and objective EOG data in a number of different sleep laboratories across the world (e.g., Dane, 1984; Dresler et al, 2012; Erlacher \& Schredl, 2008b; Fenwick et al, 1984; Hearne, 1983; Hickey, 1988; Kueny, 1985; LaBerge et al, 1981; Ogilvie at al, 1983; Voss et al, 2009; Watanabe, 2003).

Most frequently, lucid dreams are initiated from REM sleep (so called "DreamInitiated Lucid Dream” - DILD), however sometimes they can also be initiated from the waking state (“Wake-Initiated Lucid Dream” - WILD) (LaBerge, Levitan, \& Dement, 1986). Physiologically, lucid dreams are associated with elevated levels of automatic nervous system activity (LaBerge et al, 1986), but also with higher H-reflex suppression (Brylowski, Levitan, \& LaBerge, 1989). According to the recent findings, lucid REM sleep when compared to nonlucid REM sleep is associated with increased EEG $40 \mathrm{~Hz}$ power, especially in frontal and frontolateral regions (Voss, Holzmann, Tuin \& Hobson, 2009). Another recent fMRI study found increased activation during REM lucid dreaming in several brain regions, including the bilateral precuneus, cuneus, parietal lobules, and prefrontal and occipito-temporal cortices 
(Dresler et al, 2012). This specific pattern of activation might explain the presence of higher order cognitive skills involved in lucid dreaming. The prefrontal cortex is associated with metacognitive regulation and self-assessment, executive function and top-down control of behaviour, attention regulation (Arnsten \& Li, 2005; Fernandez-Duque, Baird, \& Posner, 2000; Miller \& Cohen, 2001; Schmitz, Kawahara-Baccus, \& Johnson, 2004), while the precuneus is associated with self-processing operations, such as first-person perspective taking and experience of agency (Cavanna \& Trimble, 2006). In lucid dreams the dreamer has to observe and evaluate his or her present experience to recognise the dream state and become lucid and then to take a first-person perspective and agency and guide behaviour and attention according to one's intentions in order to influence the dream content (see also Kahan \& LaBerge, 1994).

Although frequent lucid dreaming is considered to be a rare skill, the estimates of lucid dreaming incidence within the general population suggest that about a half of the population have experienced a lucid dream at least once and about one out of five people are experiencing lucid dreams regularly, i.e. at least once a month (Schredl \& Erlacher, 2011; Snyder \& Gackenbach, 1988; but cf. Stepansky et al., 1998). Differences across different cultures also exist (e.g., Erlacher, Schredl, Watanabe, Yamana, \& Gantzert (2008) found significantly lower incidence of lucid dreaming in Japanese student sample in comparison with other countries). Since the onset of lucid dream research it was demonstrated that lucid dreaming is a learnable skill (LaBerge, 1980b; see also Saint-Denys, 1867/1982) and a number of practical applications were suggested (e.g. LaBerge \& Rheingold, 1990). Lucid dreaming, for example, was successfully applied in nightmare treatment: several case studies (Abramovitch, 1995; Brylowski, 1990; Spoormaker, van den Bout, \& Meijer, 2003; Zadra \& Pihl, 1997) and a controlled trial (Spoormaker \& van den Bout, 2006) demonstrated that the development of lucid dreaming abilities can decrease nightmare frequency and nightmare 
intensity. Lucid dreaming can also be used to enhance and perfect motor performance and motor skills (Erlacher \& Schredl, 2010; Tholey, 1981) or employed for creative problem solving (Stumbrys \& Daniels, 2010). Furthermore, lucid dreaming is an invaluable tool for scientists to explore the mind-body relationship during REM sleep (see e.g. Erlacher \& Schredl, 2008a) and its uniqueness warrants lucid dreaming a special place within the whole area of consciousness research (Hobson, 2009). However, in order to utilize the advantages offered by lucid dreaming and make them available both to the scientific community and a wider population, reliable induction techniques must be established to increase the frequency of lucid dreams. This is the main challenge currently facing lucid dream research.

\subsection{Induction techniques and their classifications}

By the term "lucid dream induction" we refer to any means aiming to increase the frequency of lucid dreams. A plethora of various techniques (e.g.. Gackenbach, 1985-86; LaBerge \& Rheingold, 1990; Price \& Cohen, 1988; Tholey, 1983) has been suggested for lucid dream induction and several attempts were made to classify them.

One of the first classification systems was suggested by Gackenbach (1985-86), who classified induction techniques into two broad categories: (1) presleep induction and (2) sleep induction. The first category, presleep induction, includes intentional techniques and “unintentional considerations”. According to Gackenbach, intentional techniques focus on the

present moment (e.g. reflecting whether one is dreaming right now, engaging into other focused activities, such as meditation or alpha feedback training) or are focused on the future (e.g. autosuggestion, post-hypnotic suggestion or intention to remember that one is dreaming). Furthermore, some techniques might combine both aspects, e.g. Tholey's (1983) combined technique, which includes elements of reflection (present focussing) and intention with autosuggestion (future focussing). “Unintentional considerations” include situations during the 
day (e.g. interpersonal interactions, emotions) and individual propensities (e.g. field independence, creativity; for overview of individual differences associated with lucid dreaming see Snyder \& Gackenbach, 1988) that are not directly related to the attainment of dream lucidity but increase the likelihood of having a lucid dream. The second category, sleep induction, can be divided into external cues and internal cues. External clues are various environmental stimuli (e.g. auditory, tactile) that can be applied during REM sleep to be incorporated into a dream and recognised as a cue by the dreamer that he or she is dreaming. Internal cues can be unusual events or inconsistencies within a dream, a sense of „dreamlikeness“ or just a spontaneous insight occurring in a dream which leads to the awareness that one is dreaming.

Another classification of lucid dreaming induction techniques was suggested by Price and Cohen (1988), who grouped them into three broad classes: (1) lucid-awareness training, (2) intention and suggestion techniques and (3) cue "REM-minding” techniques. Lucidawareness training aims to cultivate a proper waking attitude to promote lucidity, such as critically reflecting on a frequent basis whether one is dreaming or not, heightening perceptual awareness, alpha feedback or waking fantasy training. Intention and suggestion techniques aspire to trigger a lucid dream through an act of will or suggestion. Examples of such techniques include intentions to carry out a specific action while dreaming (e.g. flying), to remember that one is dreaming and post-hypnotic suggestions. The third class of induction methods described by Price and Cohen (1988), cue "REM-minding” techniques, resembles Gackenbach's (1985-86) external cues category and includes tactile, auditory and other external stimuli presented during REM sleep to trigger lucidity. Price and Cohen (1988) also acknowledge that there are some other methods that do not fit into their three major classes described, such as Tholey's combined technique or hypnagogic techniques that aim to enter lucid dreams directly from the waking state at sleep onset. 
Although both these classification systems were useful and provided an adequate coverage of lucid dream induction techniques presented in literature, they seem to be fragmentary, not including all techniques. Over the recent years a number of empirical studies have been carried out that expanded our knowledge about induction techniques and new prospective methods emerged (e.g., Noreika, Windt, Lenggenhager, \& Karim, 2010). Another issue is that a considerable number of techniques included in these systems were based on personal or anecdotal accounts and lacked any empirical validation. The overlap between different categories is also a problem of these systems: Some induction methods, e.g. Tholey's combined technique, encompass both lucid awareness training and intention, or an intentional technique might result in an internal cue during a dream that will lead to the attainment of lucidity.

Therefore, in this paper we aim to present an empirically based classification of lucid dream induction techniques together with an extensive systematic review of published empirical evidence on lucid dream induction. Considering difficulties defining the exact boundaries between different groups of induction techniques, we defined the following broad categories:

(1) cognitive techniques - encompass all cognitive activities (lucid awareness training, intention, suggestion, hypnagogic techniques, etc.) that are carried out to increase the likelihood of achieving lucidity in a dream state;

(2) external stimulation - includes all types of stimuli (acoustic, light, electric, vibration, vestibular, brain stimulation, etc.) presented during REM sleep that can trigger dream lucidity;

(3) miscellaneous techniques - cover all other diverse induction methods that are not covered by the two categories above (e.g. intake of specific substances). 
We hope that such an empirically-based classification will benefit not only lucid dreaming-interested scientists, providing them most promising directions for future research and most effective means to facilitate lucid dreaming, but also a broader audience, including therapists, artists, athletes, nightmare sufferers and others who may want to purse lucid dreams for their professional or personal reasons.

\section{Method}

\subsection{Identification of studies}

A comprehensive literature search was carried out to identify relevant studies, including both electronic bibliographic databases and (lucid) dreaming specific resources. The following electronic databases were searched: MEDLINE, PsycINFO, PsycArticles, Academic Search Premier, IngentaConnect, ScienceDirect, Scopus, Web of Science, ProQuest Dissertations \& Theses Database and PSYNDEX. Specific resources included scientific journals dedicated to (lucid) dream research (such as Lucidity Letter, NightLight, International Journal of Dream Research, Dreaming), references in relevant articles and other sources (such as personal collections). When searching the literature databases, the following search query was used: dream* AND lucid* AND (induc* OR learn* OR technique* OR method* OR exercise*). For a German PSYNDEX database, in addition we also used a corresponding query with German keywords: traum* AND (luzid* OR klar*) AND (indu* OR lern* OR technik* OR method* OR $\left.\operatorname{train}^{*}\right)$.

\subsection{Inclusion and exclusion criteria}

We aimed to identify any empirical studies that were concerned with lucid dream induction or applied any methods to increase the frequency of lucid dreams in their participants. We also included those studies that were not primarily concerned with lucid dream induction but used 
some methods to promote lucid dreaming in their participants, e.g. studies that employed lucid dreaming as a treatment for nightmares. Both controlled studies in a sleep laboratory with sleep recording and quasi-experimental field studies without sleep recording were included. No language restrictions were applied. Single case reports were excluded.

\subsection{Data extraction, analysis and assessment}

Literature search was conducted in November - December 2010 by one researcher and then carried out by a second researcher in April - May 2011. Data was extracted by using a specially devised form and then was reviewed by a second researcher. The methodological quality of all studies was assessed independently by two researchers using a quality checklist developed by Downs and Black (1998), which can be used for evaluation of both randomised and non-randomised studies. The checklist contains 27 items distributed into five subscales: reporting $(n=10)$, external validity $(n=3)$, internal validity - bias $(n=7)$, internal validity confounding ( $n=6)$ and power $(n=1)$. One item on the reporting subscale (No. 5), can have a maximum score of 2, the other items are scored either 0 or 1 (although the item on power [No. 27], can get the score up to 5, in this review the maximum score for this item was considered 1). Hence the maximum score possible score for methodological quality was 28 . The Downs and Black (1998) checklist is considered to be among the six best quality assessment tools to be used for systematic reviews (Deeks et al., 2003). Any differences between the researchers were resolved by discussion. Quality scores of 21 and higher were considered good, 11 to 20 moderate and 10 and lower - poor (Hartling et al, 2004).

\section{Results}

\subsection{Literature search and excluded studies}


Initial literature search and its replication brought equivalent results: Only one additional citation was retrieved and 11 sources were no longer available on ProQuest database. In total, literature search in electronic databases yielded 131 initial references. A first examination of titles and abstracts led to the following: Eighty-three citations were rejected as not relevant, i.e. they were not dealing with lucid dream induction. Further nine citations were rejected according to our inclusion/exclusion criteria, i.e. were either not empirical studies (lacked empirical validation) or just single case studies. Four other citations (three thesis and one conference abstract) were eliminated as information in the abstract was insufficient and full texts were not available. Thus a total of 35 references were examined as full texts. After examination, 19 papers out of them were excluded as not dealing with lucid dream induction, being without an empirical validation or single case studies.

Furthermore, 22 additional papers were identified via hand search in lucid dreamingspecific resources, cited references in relevant articles and personal collections. One study identified via hand search (Ripert in Price et al, 1986) contained unrealistic data (according to the data reported, some participants had about 40 lucid dreams per night) and was judged of extremely poor quality (initial assessment by a first judge yielded 0 score on the Downs and Black (1998) checklist), hence it was discarded from further analysis.

The flowchart of the study identification process is demonstrated in Figure 1.

\subsection{Included studies}

Therefore 37 manuscripts (16 identified via literature search in electronic databases and 21 via

hand search) were included in the review. Some studies were reported in two different manuscripts (e.g., Zadra, Donderi \& Pihl, 1992; Zadra, 1991), while in two other cases (Galvin, 1993; Hickey, 1988) studies involved both sleep laboratory and field experiments witch for the purpose of this review were considered as two separate studies. Thus, a total 
number of 35 studies were analysed in this review. Details of the included studies are presented in Table 1.

\subsection{Methodological quality}

The 35 studies included in the review (11 sleep laboratory and 24 field studies) were assessed for their methodological quality independently by two researchers. The interrater reliability between the initial ratings of the two judges was very high (kappa=.91; 95\% CI 0.88-0.94). The agreed final ratings are presented in Table 2.

Taking together, the methodological quality of the studies was quite poor: The average score on the Downs \& Black's (1998) checklist was only 9.1 out of 28. Both sleep laboratory and field studies had the same level of methodological quality (9.3 and 9.0, respectively). The "reporting” subscore for the included studies averaged 4.3 out of 11 , external validity 0.7 out of 3, internal validity-bias 2.5 out of 7, and internal validity-confounding (selection bias) 1.6

out of 6 . None of the studies had a good methodological quality $(>20)$. Fourteen studies (40\%) had a moderate quality (11 to 20$)$ and 21 (60\%) poor $(<11)$. Considering the overall poor quality of the studies, small sample sizes used, great variability of the exact conditions in which induction techniques were applied and lack of reporting effect sizes respective data for computing effect sizes, it was not possible to carry out a meta-analysis. Hence our analyses will focus on a descriptive level.

\subsection{Cognitive techniques}

Twenty seven (77\%) studies employed cognitive techniques for lucid dream induction. Cognitive techniques were applied in 22 (96\%) field experiments and five (45\%) sleep laboratory studies. The following techniques were used: MILD (Mnemonic Induction of Lucid Dreams), Reflection or Reality Testing, Intention, Tholey’s Combined technique, 
Autosuggestion, Dream Re-Entry, Posthypnotic Suggestion, and Alpha Feedback. The overall methodological quality for studies involving cognitive techniques was 9.3.

\subsubsection{MILD}

MILD technique, which requires to rehearse a dream before falling asleep and visualise becoming lucid while focusing on the intention to remember that one is dreaming (LaBerge, 1980b), was the one most often tested empirically . It was applied in ten studies: nine field experiments and one sleep laboratory study. However, the only sleep laboratory study (Kueny, 1985) that involved MILD, used it only as a control condition, while the nine field studies, conducted entirely by LaBerge, Levitan and their colleagues (Edelstein \& LaBerge, 1992; LaBerge, 1988; LaBerge, Phillips, \& Levitan, 1994; Levitan, 1989; 1990a; 1990b; 1991a; Levitan \& LaBerge, 1994; Levitan, LaBerge, \& Dole, 1992), showed poor reportability scores (average "reporting” subscore was only 2.1 out of 11). The overall quality score for those nine studies was also very low (only 5.9).

It seems that MILD practice can increase the frequency of lucid dreaming (LaBerge, 1988; Levitan, 1989; 1991a; Levitan \& LaBerge, 1994). The relation between MILD practice and lucid dreaming frequency appears to be quite weak ( $\mathrm{r}=0.124)$, but significant (LaBerge, 1988). When using MILD in early morning hours, lucid dreams seem to be much more likely during following naps than the night before (Edelstein \& LaBerge, 1992; LaBerge, Phillips, \& Levitan, 1994; Levitan, 1990a; 1991a; Levitan, LaBerge, \& Dole, 1992). It appears to be favourable to wake up 30-120 minutes earlier, stay awake for those 30-120 minutes, go back to bed, practice MILD and take a nap (LaBerge, Phillips, \& Levitan, 1994; Levitan, 1990a; 1991a; Levitan, LaBerge, \& Dole, 1992). The shorter periods of wakefulness, such as taking a nap after 10 minutes (LaBerge, Phillips, \& Levitan, 1994) or immediately after awakening (Levitan, 1991a), as well as longer ones, such as taking a nap after 4 hours (Levitan, 1990a) 
or after 14-17 hours in the afternoon (Levitan, LaBerge, \& Dole, 1992), seem to be less favourable for MILD practice. MILD seems to be slightly more effective than light stimuli presented during REM sleep; however, the combination of both appears to be even more favourable for lucid dream induction (LaBerge, 1988; Levitan \& LaBerge, 1994).

\subsubsection{Reflection / reality testing}

Reflection or reality testing technique involves asking oneself regularly during the day whether one is dreaming or not, and examining the environment for possible incongruences (Tholey, 1983). Reflection / reality testing was employed in one sleep laboratory experiment (Dane, 1984), but was not used as an experimental condition, and in eight field studies (LaBerge, 1988; Levitan, 1989; Levitan \& LaBerge, 1994; Malamud, 1979; Purcell, 1988; Purcell, Mullington, Moffitt, Hoffmann, \& Pigeau, 1986; Reis, 1989; Schlag-Gies, 1992). However, one field study did not report the relevant findings (Levitan \& LaBerge, 1994) and in another study (Reis, 1989) it was used only in combination with external stimulation, so only the data from the remaining six field studies (average methodological quality 11.5) was considered.

Reflection / reality testing seems to increase frequency of lucid dreams (Levitan, 1989; Purcell, 1988; Purcell, Mullington, Moffitt, Hoffmann, \& Pigeau, 1986; Schlag-Gies, 1992), although one study did not find any relation between reality testing practice and lucid dream frequency (LaBerge, 1988). There are some indications that reflection / reality testing might be more effective than other cognitive techniques, such as autosuggestion (Levitan, 1989; Schlag-Gies, 1992), posthypnotic suggestion (Purcell, Mullington, Moffitt, Hoffmann, \& Pigeau, 1986) or intention (Schlag-Gies, 1992). Comparison with MILD is ambiguous: in one study (LaBerge, 1988) reality testing seemed to be somewhat less effective than MILD, while other study (Levitan, 1989) yielded opposite results. 


\subsubsection{Intention}

Intention technique requires that a person - before falling asleep - imagine himself or herself as intensively as possible being in a dream situation and recognise that one is dreaming (Tholey, 1983). Therefore intention technique is fairly similar to MILD, however it does not involve "mnemonic" component, i.e. while the emphasis in MILD is to remember that one is dreaming, in intention technique it is to recognise that one is dreaming. The technique was employed in four field studies; however, three of them were not specifically concerned with lucid dream induction, but used it as a means for nightmare treatment (Spoormaker, van den Bout, \& Meijer, 2003; Spoormaker \& van den Bout, 2006; Zadra \& Pihl, 1997). The fourth one compared intention technique with other induction methods (Schlag-Gies, 1992). The average methodological quality for these studies was 10.3 .

About a half of nightmare sufferers who were taught lucid dreaming with the intention technique had lucid dreams within one to three months (Spoormaker, van den Bout, \& Meijer, 2003; Spoormaker \& van den Bout, 2006; Zadra \& Pihl, 1997). The other study showed that intention technique can be successfully used for lucid dream induction; however, it seems to be somewhat less effective than reflection technique and similarly effective as autosuggestion (Schlag-Gies, 1992).

\subsubsection{Autosuggestion}

In autosuggestion technique a person suggests to himself or herself to have a lucid dream during the night while being in a relaxed stated before falling asleep (Tholey, 1983). Only two studies empirically explored autosuggestion technique (Levitan, 1989; Schlag-Gies, 1992), with an average quality score of 13.0. The findings regarding effectiveness of this technique are inhomogeneous: While in one study autosuggestion technique seemed to increase the 
number of lucid dreams (Schlag-Gies, 1992), in the other study no such effect was found (Levitan, 1989). Autosuggestion appears to be less effective than reflection / reality testing, but similarly effective as intention technique (Schlag-Gies, 1992). There are some indications that autosuggestion might be slightly more useful for frequent lucid dreamers, who have one or more lucid dreams per month (Levitan, 1989).

\subsubsection{Tholey's combined technique}

Tholey's (1983) combined technique incorporates elements of reflection, intention and autosuggestion. It involves developing a reflective frame of mind (reflection), imagining being in a dream and recognising this (intention), as well as suggesting oneself to become lucid when falling asleep (autosuggestion). Tholey's combined technique was used in two field studies (Paulsson \& Parker, 2006; Zadra, Donderi, \& Pihl, 1992). Their methodological quality was moderate (mean score 15.5). The evidence suggests that Tholey's combined technique can significantly increase the frequency of lucid dreaming, especially for those participants who had previous experience with lucid dreams (Paulsson \& Parker, 2006; Zadra, Donderi, \& Pihl, 1992). But even those participants who had not had any prior lucid dreaming experience had significantly more lucid dreams when using the technique in comparison to the controls who were not exposed to Tholey’s combined technique (Zadra, Donderi, \& Pihl, 1992).

\subsubsection{Post-hypnotic suggestion}

In post-hypnotic suggestion a hypnotherapist suggest to a person is who is in a hypnotic trance to have a lucid dream the next night. This method was used in two sleep laboratory experiments (Dane, 1984; Galvin, 1993) and two field studies (Galvin, 1993; Purcell, Mullington, Moffitt, Hoffmann, \& Pigeau, 1986). The overall quality of these studies was fair 
(mean 13.3). While in one study 14 out of 15 hypnotically susceptible women reported lucid dreams during the only night spent in a sleep laboratory (Dane, 1984), the other sleep laboratory study failed to replicate these findings (Galvin, 1993). The findings from the field experiments are also inhomogeneous: According to one study, post-hypnotic suggestion helped to increase self-reflectiveness in dreams and the majority of the participants were able to have at least one lucid dream during a nine week period (Galvin, 1993), the other study did not find any effects during a three weeks period (Purcell, Mullington, Moffitt, Hoffmann, \& Pigeau, 1986). It is notable that in the successful sleep laboratory study (Dane, 1984) posthypnotic suggestion resulted in a greater number of NREM lucid dreams than REM lucid dreams.

\subsubsection{Alpha feedback}

One sleep laboratory study (methodological quality: 11) employed EEG alpha activity biofeedback training before sleep for lucid dream induction (Ogilvie, Hunt, Tyson, Lucescu, \& Jeakins, 1982). This method was based on an assumption that lucid dreams are associated with relatively high degrees of EEG alpha frequency synchronisation. Alpha feedback training had no effect neither on lucidity nor on REM alpha levels in this study.

\subsubsection{Dream re-entry}

One field study (Levitan, 1991b) explored the method of dream re-entry, which aims to enter the dream state directly from a short awakening after a dream. The dreamer is instructed to keep still and focus his or her mind on a particular activity like counting while falling asleep. Using this approach, one might enter the dream state without losing conscious awareness (this idea has ancient origins in the Tibetan dream yoga tradition, see e.g. Wangyal, 1998). Two methods for focussing were used: "Counting” (which requires the participant to focus on 
counting while falling asleep) and "Body" (focus on the own body while falling asleep). Dream re-entry appeared to be fairly successful (43 out of 191 attempts [23\%] resulted in lucid dreams) with "Counting” method seemingly slightly more favourable than "Body"

method. Notably, participants using "Counting” method were seemingly more likely to fail to return to sleep, whereas using "Body" method they were more likely to enter sleep without dream recall. However, the methodological quality of this study was low (5).

\subsubsection{Other (eclectic) approaches}

One study (Hickey, 1988), which involved both field and sleep laboratory experiments (methodological quality 7, both) used a combination of various methods, such as MILD, reality testing, re-dreaming among others, to promote lucidity in children aged 10-12 years. Although 12 of 13 children reported at least one lucid dream in their home setting during a 6 week training period (24 lucid dreams in total) and two of four children had a verified lucid dream in a sleep laboratory (6 lucid dreams were recorded in 16 nights), due to an eclectic approach used, it is impossible to measure the exact impact of each of the techniques used.

\subsection{External stimulation}

Eleven (31\%) studies used external stimulation during REM sleep to trigger lucidity. External stimuli were employed in seven (64\%) sleep laboratory studies and four (17\%) field experiments. External stimulation involved light stimulus, acoustic stimulus, vibro-tactile stimulus, electro-tactile stimulus, vestibular bodily stimulation and water stimulus. The methodological quality of studies that employed external stimulation was 8.1.

\subsubsection{Light stimulation (including DreamLight, DreamLink, NovaDreamer)}


Light stimuli were administered in four studies: one sleep laboratory experiment (LaBerge, Levitan, Rich, \& Dement, 1988) and three field studies which used specially constructed and commercially available devices (DreamLight, DreamLink, NovaDreamer) for producing light stimuli during REM sleep (LaBerge, 1988; LaBerge \& Levitan, 1995; Levitan \& LaBerge, 1994). One field experiment (LaBerge \& Levitan, 1995) had a fair methodological quality (14), while the remaining three studies were of a rather poor quality (average: 5.0). While light cues can be successfully incorporated in dreams and trigger lucidity (LaBerge \& Levitan, 1995; LaBerge, Levitan, Rich, \& Dement, 1988), there are some indications that light stimuli might be slightly less effective than cognitive MILD technique but the combination of two seems to be even more promising (LaBerge, 1988; Levitan \& LaBerge, 1994).

\subsubsection{Acoustic stimulation}

Acoustic stimuli (such as voice "this is a dream”, a musical tone or buzzer noise) were applied in three sleep laboratory studies (Kueny, 1985; LaBerge, Owens, Nagel, \& Dement, 1981; Ogilvie, Hunt, Kushniruk, \& Newman, 1983) and one field study (Reis, 1989) with an average methodological quality of 6.3. There are some indications that acoustic stimulus might help to achieve dream lucidity (LaBerge, Owens, Nagel, \& Dement, 1981), but it is not conclusive (Kueny, 1985; Reis, 1989). One study did not find any difference between playing a voice message and a musical tone; however, it seems that gradually increasing in volume, acoustic stimuli are more effective than a constant one (Kueny, 1985). It is also possible that providing an acoustic stimulus during REM sleep with little alpha activity in the EEG might be more effective than during high alpha REM (Ogilvie et al., 1983). Other findings, however, suggest that lucidity itself might be associated with high alpha EEG activity (e.g. Ogilvie et al., 1982). 


\subsubsection{Vibro-tactile stimulation}

One field study, with a methodological quality of 6 , used vibro-tactile stimulation for lucid dream induction (Reis, 1989). While vibro-tactile stimulation, when used in combination with reflection (or also in addition combined with acoustic stimuli), resulted in some lucid dreams, due to a great variety of conditions used (e.g. training sessions received, their durations, etc.), the generalisation of findings is complicated.

\subsubsection{Electro-tactile stimulation}

Electro-tactile stimuli, applied on the wrist, were used in one sleep laboratory experiment (Hearne, 1983) with a quite good success rate: Out of 12 participants who spent a single night in a sleep laboratory, six achieved lucidity due to electric stimulation, two other subjects also achieved lucidity, but woke up at signalling and another one became lucid after falsely perceiving stimulation. The methodological quality of the study was 9 .

\subsubsection{Vestibular stimulation}

One study (Leslie \& Ogilvie, 1996) employed vestibular stimulation - participants were rocked during REM sleep at a constant frequency while sleeping in a hammock. Although findings are not conclusive, there are some indications that vestibular stimulation can increase dream reflectiveness in early vs. late morning REM periods. The methodological quality of the study was 14 .

\subsubsection{Water stimulus}


In one sleep laboratory study (Hearne, 1978), with a methodological quality score of 12 , a water stimulus was applied, i.e. some water was splashed on the face or hand of the participants. Water stimulus had no effect on dream lucidity.

\subsection{Application of drugs}

One study (LaBerge, 2004) administered an acetylcholine esterase inhibitor class drug Donepezil (AriceptÂA ${ }^{\circledR}$ - to enhance lucid dreaming. Two doses of donepezil (5 mg and 10 mg) were used as well as a control placebo condition. Nine out of 10 participants reported one or more lucid dreams in two nights, when they received donepezil, while only one participant reported a lucid dream on the control placebo night. Donepezil seemed to significantly enhance lucidity rate, frequency of sleep paralysis and increased estimated time awake during the night. The higher dose was associated with stronger effects, but seemed to provide some adverse effects (i.e. mild insomnia and gastrointestinal symptoms such as nausea and vomiting). The methodological quality of the reported study was 7.

\section{Discussion}

Thirty-five studies that explored over a dozen various techniques for lucid dream induction were examined in this review. Three classes of methods were employed by researchers to facilitate lucid dream induction: Cognitive techniques, external stimulation and drug application. Cognitive techniques are based on the continuity hypothesis of dreaming, which states that dreams reflect waking-life experiences (Schredl \& Hofmann, 2003), and aim to increase the likelihood of lucid dreams by training cognitive skills, such as prospective memory (MILD technique), self-reflection or intention. External stimulation techniques intend to trigger lucid dreams during REM sleep either by presenting a cue (visual, auditory, tactile, etc.) that might be incorporated in the dream and recognised by the dreamer or by a 
specific activation (e.g. vestibular). Finally, drug application methods aim to alter cholinergic levels of the brain to enhance lucidity in dreams. Cognitive techniques were applied mainly in field studies, while external stimuli were primarily used in sleep laboratory experiments. None of induction techniques were verified to induce lucid dreams reliably, consistently and with a high success rate. Most lucid dream induction methods produced only slight effects, although some of the techniques look promising.

One of such promising methods among cognitive techniques seems to be Tholey's combined technique, which was successfully tested in two studies with a relatively high methodological quality. MILD technique, applied in the early morning after 30-120 minutes of wakefulness, perhaps also in a combination with light stimuli presented during REM sleep, is another example, although it was explored within a single research group only. Similarly, the intention technique as well as reflection/reality testing might also be a successful means for lucid dream induction. Although only explored in a single study with a low methodological quality, dream re-entry techniques showed a good success rate and therefore need further investigation and replication. The effectiveness of autosuggestion and posthypnotic suggestion techniques is not clear. It might depend strongly on a person's hypnotic suggestibility, i.e., the high success rate in one study (Dane, 1984) with highly susceptible participants might be explained by the participants' high hypnotic suggestibility (selection criteria). Although it is an interesting idea to associate dream lucidity with alpha activity in the EEG during REM sleep, this causality of this relation seems to be unclear (cf. Ogilvie et al., 1983; Ogilvie et al., 1982) and a possibility of using such biofeedback is a rather complicated method for lucid dream induction.

Concerning external stimulation techniques, the situation is somehow less clear. Although some stimuli, such as light flashing on the eyes of a dreamer or an electrical impulse applied on the wrist during REM sleep might be effective for lucid dream induction, 
these findings should be interpreted with caution: the results were achieved in within one research group, which afterwards developed special commercially available induction devices based on these modalities (LaBerge's DreamLight, DreamLink, NovaDreamer light cue devices, Hearne's electrical “dream machine”). So there might be a bias in these findings, for example, not publishing unsuccessful trials. For instance, Venus (1982) reported little success with Hearne’s “dream machine”. Among other modalities, gradually in volume increasing acoustic stimuli might also help to achieve lucidity in dreams. Although the findings are not conclusive, vestibular and vibro-tactile stimulations showed some success and might also contribute to lucid dream induction, but further investigations with these modalities are needed. It is much less clear whether water stimuli can possibly trigger lucid dreams. While in most cases lucidity is attained when a dreamer recognises a prearranged external stimulus as a cue in the dream that he or she is dreaming, in some cases an external cue can trigger lucidity even without being actively recognised by the dreamer (e.g. LaBerge et al, 1981; LaBerge et al, 1988). However, for successful recognition of a cue during the dream some cognitive preparation might also be needed - the dreamer should have an appropriate mindset to recognize the cue.

A separate category of induction techniques, which was not covered in earlier reviews (e.g. Gackenbach, 1985-86; Price \& Cohen, 1988), emerged in this review - drug application as a means to induce lucid dreaming. While only donepezil was tested empirically (LaBerge, 2004), it has been speculated that also other substances, such as DMAE (2dimethylaminoethanol), rivastigmin, galantamine, huperzine, can enhance lucidity in dreams via altering cholinergic system, i.e. increasing the levels of acetylcholine in the brain (LaBerge, 2004; Sergio, 1988; see also Yuschak, 2006). Although the only study showed some success with donepezil, more rigorous studies have to be carried out in order to have a 
better picture of the effects of such substances, paying special attention to adverse effects like insomnia and gastrointestinal symptoms.

On the basis of the reviewed studies, we present a taxonomy of lucid dream induction methods (Table 3), which is based on empirical evidence identified in this review. Induction techniques are first classified into the three broad categories cognitive techniques, external stimulation and miscellaneous methods.

Cognitive techniques are divided further into DILD and WILD, in accordance with a suggestion by LaBerge and Rheingold (1990), as these two categories represent two different approaches in initiation of lucid dreams. With the former, lucid dream is initiated from within a dream, i.e. a person becomes lucid during a dream, while with the latter, one aims to retain conscious awareness when falling asleep and directly (re)enter the dream state. WILD techniques (also called techniques for retaining lucidity) can be used either immediately after awakening from a dream (dream re-entry, Levitan, 1991b) or after some period of wakefulness (Tholey, 1983). In miscellaneous techniques, we include drug application and WBTB (Wake-up-Back-To-Bed) method (Erlacher, 2010), where a person goes back to bed and takes a nap after a certain period of awakening (e.g. 30-120 min) during early morning hours (Edelstein \& LaBerge, 1992; LaBerge, Phillips, \& Levitan, 1994; Levitan, 1990a; 1991a; Levitan, LaBerge, \& Dole, 1992). Although WBTB was tested empirically in combination with MILD only, it seems to be a method for facilitating lucidity on its own and perhaps might be successfully applied in combination with other induction techniques.

To provide a clearer picture of possible efficacy of induction methods, we have employed a traffic light metaphor to code the effectiveness evidence levels. Green colour was designated to those induction methods that were demonstrated to be successful in at least two empirical studies without divergent evidence. Yellow colour was used for those methods that showed some success when tested empirically, but the findings were not replicated or are 
ambiguous. Finally, red colour was assigned to those methods which verification was unsuccessful. These designated effectiveness evidence levels, however, do not take into account methodological rigorousness of the studies included. For example, although Tholey’s combined technique was verified in two studies only, both of these had a fair methodological quality and were carried out by independent research groups, while MILD was explored in nine field experiments, but within a single research group and very poor methodological rigorousness.

While conducting the review, we also identified a number of proposed lucid dream induction methods that were not tested empirically and warrant further investigation. Among cognitive techniques, such methods include WILD techniques based on concentration on hypnagogic imagery or actively visualision (LaBerge \& Rheingold, 1990; Tholey, 1983). For external stimulation, transcranial magnetic simulation (TMS) and transcranial direct current stimulation (tDCS) are proposed to be applied during REM sleep (Karim, 2010; Noreika et al, 2010) which can increase cortical excitability of brain structures that are supposedly linked to lucid dreaming, such as the dorsolateral prefrontal cortex (DLPFC) (Hobson et al., 2000) and therefore trigger lucidity in dreams. Alternatively, galvanic vestibular stimulation (GVS) can be used for direct stimulation of vestibular system (Noreika et al, 2010), which is also linked to lucid dreaming (cf. Leslie \& Ogilvie, 1996). In addition to donepezil, galantamine, rivastigmin, huperzine and DMAE have been suggested as drugs that can enhance lucidity in dreams (LaBerge, 2004; Sergio, 1988).

Before discussing in details methodological issues pertaining the studies reviewed, some limitations should be made about the methodology of the present review. Although we put an extensive effort in locating all possible existing evidence on lucid dream induction, it may still be that some evidence remained unidentified. Also we had to restrict ourselves to evaluate only such evidence which has been published at least in some form (e.g. journal 
article, thesis/dissertation, conference abstract, etc.). This might have affected the assessment of some evidence which was only partially available in a published form (e.g. conference presentations where only abstracts were available without the actual content of the presentation) and therefore was evaluated only according to what was published, but not necessary to what was actually presented, as the presenter might have clarified some points during the presentation itself. Finally, the methodological quality checklist used in this study (Downs \& Black, 1998) is more tailored to evaluate clinical (medical) studies and its assessment criteria might have been too rigorous for the evaluation of studies within a more explorative field of lucid dream research. There were items, for example, 8 (assessment of adverse effects), 11 and 12 (representative sampling) or 24 (concealment of randomisation both from participants and staff), that were always or nearly always scored as 0 .

The review revealed a number of methodological issues related both to the methodological quality of the studies reviewed and lucid dream research in general. While the application of a rigorous checklist might not have revealed all subtle methodological quality differences within the studies reviewed, the assessment results are nevertheless indicative. None of the reviewed studies can be considered as having a good methodological quality and the majority of the studies were rather methodologically poor. Based on our assessment, some suggestions for researchers on how to improve the methodological quality of their studies can be provided.

Firstly and foremostly, researchers should pay special attention to how they are reporting their studies. Many papers do not clearly describe the main outcomes to be measured and detailed outcome data, including estimates of the random variability (standard deviations, confidence intervals, etc) and especially effect sizes. We were not able to carry out a meta-analysis regarding the effectiveness of different induction techniques and had to limit the review to a descriptive level. Reporting of effect sizes would allow proper meta-analysis 
and more accurate comparisons among different techniques to be done. Principal confounders and any adverse effects also have to be noted when reporting studies.

All reviewed studies lacked external validity - most participants were self-selected lucid dreamers or university students which makes it impossible to generalise the findings. Although it might be difficult to conduct a study with a representative sample, some attempt could be made to improve external validity (e.g. do the same study with different samples).

Internal validity was also an issue for many studies. Most studies were not blinded both for participants and those measuring the outcomes. In field studies, compliance with the study procedure was not always reliable - only few studies had some additional means (e.g. detailed questionnaires to be filled) to monitor if the participants have followed the exact procedure. Validity and reliability of outcome measures was another problem for some studies (see discussion about a criterion for successful induction below). Some studies relied only on participants' subjective judgement whether they had a lucid dream or not, which sometimes might be fallacious (see Snyder \& Gackenbach, 1988) and some extra measures (e.g. external raters of dream reports) might be useful.

Finally, the vast majority of the reviewed studies lacked sufficient power to detect significant effects. Researchers are advised to consider possible effect sizes beforehand and calculate their sample sizes accordingly.

One of the major issues concerning lucid dream induction research in general is what to define a valid criterion for successful induction. The strict criterion for sleep laboratory studies would be unambiguous predefined eye signals on the EOG during REM or NREM sleep (see below) and a dream report received immediately after awakening following signalling, which confirms lucidity and volitional eye signals. The situation is less clear when (1) only eye signals are present on the EOG without a fully confirmatory dream report, or (2) only dream report is present that indicates lucidity, but no predefined eye signals are visible 
on the EOG or they are ambiguous. The latter situation is encountered in field experiments also, where no polysomnographic sleep recording is being carried out. Some field studies (e.g., LaBerge \& Levitan, 1995; Purcell et al, 1986; Zadra et al, 1992) employed external blinded judges to score dream reports for lucidity, but even with this approach the validation of lucid dreams is complicated: It would still rely on the dreamer's recollection of the dream, which might be impaired by sleep inertia - a transitional state between sleep and wakefulness in which cognitive performance is decreased (Tassi \& Muzet, 2000), especially if the dream was not recorded immediately after awakening. This also brings a further issue of introspection - subjective dream reports are very difficult to verify and while the presence of predefined eye-movement on the EOG can be considered as an objective verification, their absence leaves the question of verification open (cf. Nisbett \& Wilson, 1977). Although the presence of predefined eye signals in the EOG but absence of a confirmatory dream report, might also be a result of sleep inertia, it is also possible that regular eye movements during REM sleep just accidently corresponded with the predefined signal. To minimize such a risk, longer sequences of predefined eye movements (e.g. LRLRLR) should be used instead of shorter ones (e.g. LRLR). Furthermore, to consider a dream as lucid unambiguously, the person should also be convinced that he or she is dreaming, because in some cases (e.g. Dane, 1984) researchers encouraged their participants to make a signal even if they were not sure whether they are dreaming or not. More sophisticated communication with the dreamer might also be devised, so that participants can give one signal when they think they are dreaming (e.g. LRLRLR) and another signal (e.g. LRLRLRLR) when they consider themselves awake.

Further, although lucidity sometimes is considered a sort of "all-or-nothing" phenomenon, i.e. either the dreamer knows that he or she is dreaming and is lucid or does not realise this and therefore is not lucid, it seems that there are different degrees of lucidity within dreams and in some dreams a person might be more lucid than in others, which 
suggests a continuum of dream lucidity (Barrett, 1992; Moss, 1986). Different degrees of lucidity usually are not taken into account in the induction studies. Purcell and co-workers developed a dream self-reflectiveness scale (Purcell, 1988; Purcell et al, 1986); however, it involves only two categories for dream lucidity and control. On the other hand, some researchers are using even more specific requirements for dreams to be considered as lucid dreams. While the conventional (minimal) criterion for a lucid dream is awareness of dreaming during the dream, Schlag-Gies (1992), for example, considers a dream as lucid only if some consequences arise from the awareness of being in the dream (e.g. intention to change the setting). Therefore, detailed lucidity scales must be devised in order to discriminate those different degrees of lucidity and their associations with different induction techniques. This would allow comparing induction methods both on qualitative and qualitative basis.

Furthermore, possible differences between sleep laboratory studies and field experiments for lucid dream induction must also be considered. Dreams obtained in sleep laboratory studies usually show a high rate of laboratory references (Schredl, 2008), which might be an additional trigger for dream lucidity. The participants who are coming to a sleep laboratory specifically for the experiment (sometimes they are even paid for that) and know that they will be observed by the experimenters through the whole night might be more motivated than of those participants who are carrying experimental procedures in their home setting. On the other hand, the pressure to produce a lucid dream might be very high and can even interfere with sleeping well enough to produce REM sleep and lucid dreams.

The time at which lucid dream induction techniques are applied might also be a crucial factor for the success of the technique. For example, as it was already noted, MILD technique if applied in the early morning hours (e.g. with WBTB method) seems to produce more lucid dreams. Therefore researchers should also put a time factor into consideration, i.e., explore when a particular technique should be applied for the best results. 
The sleep stage in which a lucid dream occurs should also be taken into consideration. Although lucid dreams by a large extent happen in REM sleep and are mainly considered REM phenomena (LaBerge, 1990), they can also occur in NREM sleep. For example, Dane’s (1984) study had an unusually high number of signal verified NREM lucid dreams, recorded both in NREM1 and NREM2 stages of sleep. While to our knowledge, none of lucid dreams has been recorded in NREM3 stage of sleep, self-awareness in deep sleep might also be possible (cf. Mason et al., 1997). Hobson (2009) proposes that lucid dreaming represent a dissociative state with elements of both waking and dreaming, while the alternative hypothesis is that REM sleep (and perhaps to some extent NREM sleep as well) is capable of supporting reflective consciousness (LaBerge, 2010). Further research should explore differences between REM and NREM lucid dreams in greater details. It might be that different techniques have a different success rate in eliciting REM and NREM lucid dreams.

It is also very likely that some techniques will work better for some people than others. For example, Levitan (1989) found that autosuggestion was most successful for frequent lucid dreamers while had a very little success for infrequent or non-lucid dreamers. It might be that individual differences will also play a role in success for a particular technique. For example, it might be that for highly hypnotically susceptible people post-hypnotic suggestion will work well, while those with good prospective memory skills might benefit from MILD or those with good attention might be most successful with recognising an external cue. Those individual differences and the level of experience should also be considered when testing different techniques.

Finally, the overall trend regarding the number of studies carried out in lucid dream research is alarming. Out of 37 manuscripts included in this review, two were published in 1970s, 16 in 1980s, 15 in 1990s and only four in 2000s. After a "golden age” of lucid dream research in 1980s and 90s, the scientific interest in lucid dreams seems to be declining 
dramatically. However, with the help of new brain imaging technologies that are becoming available for lucid dream research (Dresler et al., 2011), lucid dreaming might become an invaluable tool for understanding the dreaming brain and wider questions of consciousness. But both to progress lucid dream research and make lucid dreaming available to wider populations, reliable induction techniques must be established. No single technique showed to be effective enough to facilitate lucid dreams with a high success rate and perhaps a more eclectic approach might be useful in lucid dream induction: To combine different techniques and advantages offered by them. Sleep laboratory research perhaps can benefit from a combination of cognitive techniques and external stimulation delivered during REM sleep. Inclusion of WBTB and/or ingestion of specific substances might increase odds for lucidity further, but a special word of caution should be made regarding the use of chemical substances: Their effectiveness must be explored in clinical trials and adverse effects should be carefully monitored, especially those occurring after chronic use of such substances. Combination of cognitive techniques and WBTB might be the most appropriate solution for "home lucid dreaming” and the dreamers can also benefit from specially developed devices that can identify REM sleep and deliver external cues. Increasing public interest in lucid dreaming and active online dreamers' communities where people are sharing their experiences and tips for successful lucid dreaming might be another soil that would yield another generation of lucid dream induction techniques.

\section{$5 \quad$ Future directions}

We hope that the present review will serve as a new starting point in the lucid dream science, inviting researchers to further explore the most promising directions for induction research and to employ the most effect techniques for general lucid dream research and practical applications. The following ideas, we believe, are worth to tackle and pursue further. 
The techniques that showed to be most effective, such as Tholey's combined technique or MILD, should be tested further and the circumstances under which they are most successful should be explored (e.g. in combination with WBTB). Also the methods that demonstrated some initial success but were not further investigated (e.g. WILD techniques, vibro-/electro-tactile, vestibular stimulations) must be more thoroughly tested. Application of the Acetylcholinesterase inhibitor class drugs, such as donepezil, galantamine, rivastigmin, definitely warrant further investigation, as well as new prospective yet untested methods like tDCS, TMS or GVS (Noreika et al, 2010). While the different methods and their effects on dream lucidity have to be tested separately, it may well be that more eclectic approaches combining the advantages of different techniques will show to be the most effective (e.g. to do a cognitive technique after awakening in early morning hours (WBTB) while taking an Acetylcholinesterase inhibitor drug and applying an external stimulation in a subsequent REM period). We also advise researchers to take into account the methodological considerations described above both to increase the quality of their studies and reports and shed more light on other factors (e.g. individual differences, sleep stages, timings) that may play an important role in promoting conscious awareness in dreams.

Effective lucid dream induction, allowing to have lucid dreams on demand, will open exciting opportunities both for dream/consciousness research and practical applications. With new brain imaging methods further differences can be elicited comparing lucid and non-lucid REM sleep (e.g. Dresler et al, 2012), mapping brain regions involved in self-reflective awareness and secondary consciousness in dreams. This may also help to clarify whether lucid dreaming should be considered as a distinctive hybrid state - a mixture - of REM sleep and wakefulness or only as a special instance of REM sleep (cf. Hobson, 2009; LaBerge, 2010). A possible induction of NREM lucid dreaming will make those questions even more interesting. Further, availability of lucid dreaming for brain imaging, will open opportunities 
to explore the neural correlates of specific dream mentation as well as "dream reading" inferring dream content from its underlying neural activity (Dresler et al, 2011).

Finally, effective induction techniques will make practical applications of lucid dreams possible for wider audiences. Nightmare sufferers could employ lucid dreaming techniques to decrease their nightmare frequency and intensity (Abramovitch, 1995; Brylowski, 1990; (Spoormaker \& van den Bout, 2006; Spoormaker, van den Bout, \& Meijer, 2003; Zadra \& Pihl, 1997). Athletes could use this to improve their performance, perfect existing motor skills and acquire new ones, explore more risky actions, practice without fear of injury or negative judgements, manipulate phenomenal space and time (Erlacher \& Schredl, 2010; Tholey, 1981, 1990). Similarly, lucid dreaming could be used to rehearse any skill (e.g. presenting in front of an audience) to reduce performance anxiety and increase self-confidence (LaBerge \& Rheingold, 1990). Lucid dreams can also be employed for creative problem solving - for example, by asking a dream character for a creative advice (Stumbrys \& Daniels, 2010). Opportunities for self-integration, growth, development of mental flexibility, spirituality are also present in lucid dreams (LaBerge \& Rheingold, 1990). While the benefits of lucid dreams currently are utilised only by a few (for example, Erlacher, Stumbrys and Schredl (20112012) in a sample of 840 German athletes found that only 5\% of them used the lucid dream state to practice sport skills), efficient techniques could unlock these hidden potentials for much broader audiences.

\section{References}

Abramovitch, H. (1995). The nightmare of returning home: a case of acute onset nightmare disorder treated by lucid dreaming. Israel Journal of Psychiatry and Related Sciences, 32(2), 140-5.

Aristotle. (2007). On Dreams. eBooks@Adelaide. Retrieved February 23, 2012, from http://ebooks.adelaide.edu.au/a/aristotle/dreams/complete.html. 
Arnsten, A. F. T., \& Li, B.-M. (2005). Neurobiology of executive functions: catecholamine influences on prefrontal cortical functions. Biological Psychiatry, 57(11), 1377-84.

Barrett, D. (1992). Just how lucid are lucid dreams? Dreaming, 2(4), 221-228.

Brylowski, A. (1990). Nightmares in crisis: clinical applications of lucid dreaming techniques. Psychiatric Journal of the University of Ottawa, 15(2), 79-84.

Brylowski, A., Levitan, L., \& LaBerge, S. (1989). H-reflex suppression and autonomic activation during lucid REM sleep: a case study. Sleep, 12(4), 374-378.

Cavanna, A. E., \& Trimble, M. R. (2006). The precuneus: a review of its functional anatomy and behavioural correlates. Brain, 129, 564-83.

Dane, J. R. (1984). A Comparison of Waking Instructions and Posthypnotic Suggestion for Lucid Dream Induction. Unpublished doctoral dissertation. Georgia State University, US.

Dane, J. R., \& Van De Castle, R. L. (1984). A comparison of waking instruction and posthypnotic suggestion for lucid dream induction. Lucidity Letter, 3(4).

Deeks, J. J., Dinnes, J., D’Amico, R., Sowden, a J., Sakarovitch, C., Song, F., Petticrew, M., et al. (2003). Evaluating non-randomised intervention studies. Health Technology Assessment, 7(27), 1-173.

Downs, S. H., \& Black, N. (1998). The feasibility of creating a checklist for the assessment of the methodological quality both of randomised and non-randomised studies of health care interventions. Journal of Epidemiology and Community Health, 52(6), 377-84.

Dresler, M., Koch, S. P., Wehrle, R., Spoormaker, V. I., Holsboer, F., Steiger, A., Sämann, P. G., Obrig, H., Czisch, M. (2011). Dreamed movement elicits activation in the sensorimotor cortex. Current Biology, 21(21), 1833-1837.

Dresler, M., Wehrle, R., Spoormaker, V. I., Koch, S. P., Holsboer, F., Steiger, A., Obrig, H., et al. (2012). Neural correlates of dream lucidity obtained from contrasting lucid versus non-lucid REM sleep: a combined EEG/fMRI case study. Sleep, in press.

Edelstein, J., \& LaBerge, S. (1992). The best time for lucid dreaming: Naps, mishaps, and recaps. NightLight, 4(2), 4, 9.

Erlacher, D. (2009). Recall of a specific word list in lucid dreams: An explorative online study. International Journal of Dream Research, 2(1), 37-40.

Erlacher, D. (2010). Anleitung zum Klarträumen. Die nächtliche Traumwelt selbst gestalten. Norderstedt: BoD.

Erlacher, D., \& Schredl, M. (2008a). Do REM (lucid) dreamed and executed actions share the same neural substrate? International Journal of Dream Research, 1(1), 7-13. 
Erlacher, D., \& Schredl, M. (2008b). Cardiovascular responses to dreamed physical exercise during REM lucid dreaming. Dreaming, 18(2), 112-121.

Erlacher, D., \& Schredl, M. (2010). Practicing a motor task in a lucid dream enhances subsequent performance: A pilot study. The Sport Psychologist, 24(2), 157-167.

Erlacher, D., Schredl, M., Watanabe, T., Yamana, J., \& Gantzert, F. (2008). The incidence of lucid dreaming within a Japanese university student sample. International Journal of Dream Research, 1(2), 39-43.

Erlacher, D., Stumbrys, T., \& Schredl, M. (2011-2012). Frequency of lucid dreams and lucid dream practice in German athletes. Imagination, Cognition and Personality, 31(3), 237246.

Fenwick, P., Schatzman, M., Worsley, A., Adams, J., Stone, S., \& Baker, A. (1984). Lucid dreaming: correspondence between dreamed and actual events in one subject during REM sleep. Biological Psychology, 18(4), 243-52.

Fernandez-Duque, D., Baird, J. A, \& Posner, M. I. (2000). Executive attention and metacognitive regulation. Consciousness and Cognition, 9, 288-307.

Gackenbach, J. I. (1985). A survey of considerations for inducing conscious awareness of dreaming while dreaming. Imagination, Cognition and Personality, 5(1), 41-55.

Galvin, F. J. (1993). The effects of lucid dream training upon the frequency and severity of nightmares. Unpublished doctoral dissertation. Boston University, US.

Gillespie, G. (1984). Can we distinguish between lucid dreams and dreaming awareness dreams? Lucidity Letter, 3(2\&3), 9-11.

Hearne, K. M. T. (1978). Lucid Dreams: An Electro-Physiological and Psychological Study. . Unpublished doctoral dissertation. University of Liverpool, UK.

Hearne, K. M. T. (1983). Lucid dream induction. Journal of Mental Imagination, 7(1), 19-24.

Hartling, L., Brison, R. J., Crumley, E. T., Klassen, T. P., \& Pickett, W. (2004). A systematic review of interventions to prevent childhood farm injuries. Pediatrics, 114(4), e483-96.

Hickey, D. A. (1988). The validation of lucid dreams in school age children. Sleep Research, $17,114$.

Hobson, J. A. (2009). The neurobiology of consciousness: Lucid dreaming wakes up. International Journal of Dream Research, 2(2), 41-44.

Hobson, J. A., Pace-Schott, E. F., \& Stickgold, R. (2000). Dreaming and the brain: Toward a cognitive neuroscience of conscious states. Behavioral and Brain Sciences, 23(6), 793842; discussion 904-1121.

Kahan, T. L., \& LaBerge, S. (1994). Lucid dreaming as metacognition: Implications for cognitive science. Consciousness and Cognition, 3, 246-264. 
Karim, A. A. (2010). Transcranial cortex stimulation as a novel approach for probing the neurobiology of dreams: Clinical and neuroethical implications. Commentary on "The neurobiology of consciousness: Lucid dreaming wakes up” by J. Allan Hobson. International Journal of Dream Research, 3(1), 17-20.

Kueny, S. R. (1985). An Examination of Auditory Cueing in REM Sleep for the Induction of Lucid Dreams. Unpublished doctoral dissertation. Pacific Graduate School of Psychology, US.

LaBerge, S. (1985). Lucid dreaming. The power of being awake and aware in your dreams. Los Angeles: Tarcher.

LaBerge, S. (1987). Induction of lucid dreaming by luminous stimulation. Lucidity Letter, $6(2)$.

LaBerge, S. (1988). Induction of lucid dreams including the use of the Dreamlight. Lucidity Letter, 7(2).

LaBerge, S. (1990). Lucid dreaming: Psychophysiological studies of consciousness during REM sleep. In R. R. Bootzen, J. F. Kihlstrom, \& D. L. Schacter (Eds.), Sleep and Cognition (pp. 109-126). Washington, D.C: American Psychological Association.

LaBerge, S. (2010). Signal-verfied lucid dreaming proves that REM sleep can support reflective consciousness. Commentary on "The neurobiology of consciousness: Lucid dreaming wakes up” by J. Allan Hobson. International Journal of Dream Research, 3(1), 26-27.

LaBerge, S. P. (1980a). Lucid dreaming: An exploratory study of consciousness during sleep. Unpublished doctoral dissertation. Stanford University, US.

LaBerge, S. P. (1980b). Lucid dreaming as a learnable skill: A case study. Perceptual and Motor Skills, 51(3 Pt 2), 1039-1042.

LaBerge, S. P. (2004). Substances that enhance recall and lucidity during dreaming. United States Patent Application Publication No. US 2004/0266659 A1.

LaBerge, S. P., Nagel, L. E., Dement, W. C., \& Zarcone, V. P. J. (1981). Lucid dreaming verified by volitional communication during REM sleep. Perceptual and Motor Skills, 52(3), 727-732.

LaBerge, S., \& Levitan, L. (1995). Validity established of DreamLight cues for eliciting lucid dreaming. Dreaming, 5(3), 159-168.

LaBerge, S., Levitan, L., \& Dement, W. (1986). Lucid dreaming: Physiological correlates of consciousness during REM sleep. Journal of Mind and Behavior, 7(2-3), 251-258.

LaBerge, S., Levitan, L., Rich, R., \& Dement, W. C. (1988). Induction of lucid dreaming by light stimulation during REM sleep. Sleep Research, 17, 104. 
LaBerge, S., Owens, J., Nagel, L. E., \& Dement, W. C. (1981). “This is a dream”: Induction of lucid dreams by verbal suggestion during REM sleep. Sleep Research, 10, 150.

LaBerge, S., Phillips, L., \& Levitan, L. (1994). An hour of wakefulness before morning naps makes lucidity more likely. NightLight, 6(3), 1-4, 9.

LaBerge, S., \& Rheingold, H. (1990). Exploring the World of Lucid Dreaming. New York: Ballantine Books.

Leslie, K., \& Ogilvie, R. D. (1996). Vestibular dreams: The effect of rocking on dream mentation. Dreaming, 6(1), 1-16.

Levitan, L. (1989). A comparison of three methods of lucid dream induction. NightLight, 1(3), 3, 9-12.

Levitan, L. (1990a). The best time for lucid dreaming. NightLight, 2(3), 9-11.

Levitan, L. (1990b). Is fifteen minutes enough? It's too soon to tell... NightLight, 2(4), 4, 14.

Levitan, L. (1991a). Get up early, take a nap, be lucid! NightLight, 3(1), 1-4, 9.

Levitan, L. (1991b). Between wakefulness and sleep. NightLight, 3(4), 4, 9-11.

Levitan, L., \& LaBerge, S. (1994). Of the MILD technique \& dream recall, of minds \& dream machines. NightLight, 6(2), 9-12.

Levitan, L., LaBerge, S., \& Dole, J. (1992). Morning naps are better than afternoon naps for lucid dreaming. NightLight, 4(4), 4, 9-10.

Malamud, J. R. (1979). The Development of a Training Method for the Cultivation of "Lucid" Awareness in Fantasy, Dreams, and Waking Life. Unpublished doctoral dissertation. New York University, US.

Mason, L. I., Alexander, C. N., Travis, F. T., Marsh, G., Orme-Johnson, D. W., Gackenbach, J., Mason, D. C., Rainforth, M., Walton, K. G. (1997). Electrophysiological correlates of higher states of consciousness during sleep in long-term practitioners of the 9Transcendental Meditation program. Sleep, 20(2), 102-10.

Miller, E. K., \& Cohen, J. D. (2001). An integrative theory of prefrontal cortex function. Annual Review of Neuroscience, 24, 167-202.

Moss, K. (1986). The dream lucidity continuum. Lucidity Letter, 5(2), 25-28.

Nisbett, R. E., \& Wilson, T. D. (1977). Telling more than we can know: Verbal reports on mental processes. Psychological Review, 84(3), 231-259.

Noreika, V., Windt, J. M., Lenggenhager, B., \& Karim, A. A. (2010). New perspectives for the study of lucid dreaming: From brain stimulation to philosophical theories of selfconsciousness. Commentary on "The neurobiology of consciousness: Lucid dreaming wakes up” by J. Allan Hobson. International Journal of Dream Research, 3(1), 36-45. 
Ogilvie, R., Hunt, H., Kushniruk, A., \& Newman, J. (1983). Lucid dreams and the arousal continuum. Lucidity Letter, 2(2), 49.

Ogilvie, R. D., Hunt, H. T., Tyson, P. D., Lucescu, M. L., \& Jeakins, D. B. (1982). Lucid dreaming and alpha activity: a preliminary report. Perceptual and Motor Skills, 55(3 Pt 1), 795-808.

Paulsson, T., \& Parker, A. (2006). The effects of a two-week reflection-intention training program on lucid dream recall. Dreaming, 16(1), 22-35.

Price, R. F., \& Cohen, D. B. (1988). Lucid dream induction: An empirical evaluation. In J. Gackenbach \& S. LaBerge (Eds.), Conscious Mind, Sleeping Brain: Perspectives on Lucid Dreaming (pp. 105-134). New York: Plenum Press.

Price, R., LaBerge, S., Bouchet, C., Ripert, R., \& Dane, J. (1986). The problems of induction. Lucidity Letter, 5(1).

Purcell, S. D. (1988). The education of attention to dreaming in high and low frequency dream recallers: The effects on dream self-reflectiveness lucidity and control. Unpublished doctoral dissertation. Carleton University, Canada.

Purcell, S., Mullington, J., Moffitt, A., Hoffmann, R., \& Pigeau, R. (1986). Dream selfreflectiveness as a learned cognitive skill. Sleep, 9(3), 423-437.

Reis, J. (1989). Entwicklung Einer Biofeedback-Technik zur Induktion von Klartraumen. Bewusst Sein, 1(1), 57-66.

Roffwarg, H. P., Dement, W. C., Muzio, J. N., \& Fisher, C. (1962). Dream imagery: Relationship to rapid eye movements of sleep. Archives of General Psychiatry, 7(4), 235-258.

Saint-Denys, H. D. (1982). Dreams and How to Guide Them. (M. Schatzman, Trans.). London: Duckworth. (Original work published 1867).

Schlag-Gies, C. (1992). Untersuchung der Effektivität zur Induktion von Klarträumen. Unpublished diploma thesis. Saarland University, Germany.

Schredl, M. (2008). Laboratory references in dreams: Methodological problem and/or evidence for the continuity hypothesis of dreaming? International Journal of Dream Research, 1(1), 3-6.

Schredl, M., \& Erlacher, D. (2011). Frequency of lucid dreaming in a representative German sample. Perceptual and Motor Skills, 112(1), 104-108.

Schredl, M., \& Hofmann, F. (2003). Continuity between waking activities and dream activities. Consciousness and Cognition, 12(2), 298-308.

Schmitz, T. W., Kawahara-Baccus, T. N., \& Johnson, S. C. (2004). Metacognitive evaluation, self-relevance, and the right prefrontal cortex. NeuroImage, 22(2), 941-7. 
Sergio, W. (1988). Use of DMAE (2-dimethylaminoethanol) in the induction of lucid dreams. Medical Hypotheses, 26(4), 255-257.

Snyder, T., \& Gackenbach, J. (1988). Individual differences associated with lucid dreaming. In J. Gackenbach \& S. LaBerge (Eds.), Conscious Mind, Sleeping Brain: Perspectives on Lucid Dreaming (pp. 221-259). New York: Plenum Press.

Spoormaker, V. I., Bout, J. van den, \& Meijer, E. J. G. (2003). Lucid dreaming treatment for nightmares: A series of cases. Dreaming, 13(3), 181-186.

Spoormaker, V. I., \& Den Bout, J. van. (2006). Lucid dreaming treatment for nightmares: a pilot study. Psychotherapy and Psychosomatics, 75(6), 389-394.

Stepansky, R., Holzinger, B., Schmeiser-Rieder, A., Saletu, B., Kunze, M., \& Zeitlhofer, J. (1998). Austrian dream behavior: Results of a representative population survey. Dreaming, 8(1), 23-30.

Stumbrys, T., \& Daniels, M. (2010). An exploratory study of creative problem solving in lucid dreams: Preliminary findings and methodological considerations. International Journal of Dream Research, 3(2), 121-129.

Tart, C. (1984). Terminology in lucid dream research. Lucidity Letter, 3(1), 4-6.

Tart, C. (1985). What do we mean by lucidity? Lucidity Letter, 4(2), 12-17.

Tassi, P., \& Muzet, A. (2000). Sleep inertia. Sleep Medicine Reviews, 4(4), 341-353.

Tholey, P. (1981). Empirische Untersuchungen über Klarträume. Gestalt Theory, 3(1/2), 2162.

Tholey, P. (1983). Techniques for inducing and manipulating lucid dreams. Perceptual and Motor Skills, 57, 79-90.

Tholey, P. (1985). Haben Traumgestalten ein Bewußtsein? Eine experimentellphänomenologische Klartraumstudie. Gestalt Theory, 7, 29-46.

Tholey, P. (1990). Applications of lucid dreaming in sports. Lucidity Letter, 9, 6-17.

Venus, S. (1982). Early Results With Hearne’s Dream Machine. Lucidity Letter, 1(2), 7.

Voss, U., Holzmann, R., Tuin, I., \& Hobson, J. A. (2009). Lucid dreaming: a state of consciousness with features of both waking and non-lucid dreaming. Sleep, 32(9), 1191200.

Wangyal, T. (1998). The Tibetan Yogas of Dream and Sleep. New York: Snow Lion Publications.

Watanabe, T. (2003). Lucid dreaming: Its experimental proof and psychological conditions. Journal of International Society of Life Information Science, 21(1), 159-162. 
Yuschak, T. (2006). Advanced Lucid Dreaming. The Power of Supplements. Lulu Press.

Zadra, A. (1991). Lucid Dreaming as a Learnable Skill: Empirical and Clinical Findings. Unpublished Master’s thesis. McGill University, Canada.

Zadra, A. L., Donderi, D. C., \& Pihl, R. O. (1992). Efficacy of lucid dream induction for lucid and non-lucid dreamers. Dreaming, 2(2), 85-97.

Zadra, A. L., \& Pihl, R. O. (1997). Lucid dreaming as a treatment for recurrent nightmares. Psychotherapy and Psychosomatics, 66(1), 50-55. 
Figure 1. Study identification flow chart

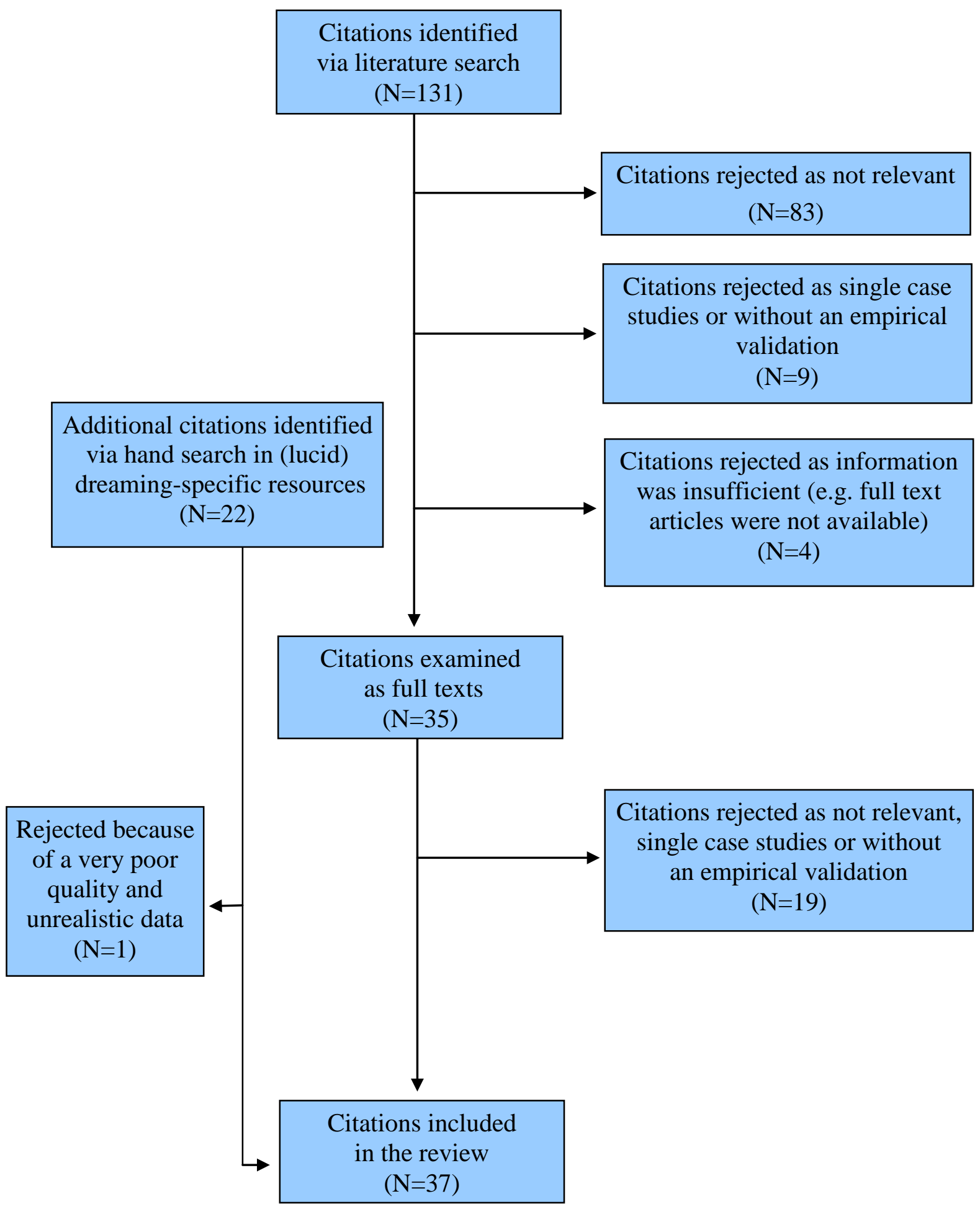


Table 1. Included studies

\begin{tabular}{|c|c|c|c|c|c|c|c|}
\hline No & Reference & Type & Methods & Sample & $\begin{array}{l}\text { Techniques } \\
\text { used }\end{array}$ & Main results & Quality \\
\hline 1 & Levitan, 1989 & $\begin{array}{l}\text { Field } \\
\text { (within) }\end{array}$ & $\begin{array}{l}4 \text { weeks; different technique } \\
\text { each week ( } 1^{\text {st }} \text { week - baseline } \\
\text { with no technique). }\end{array}$ & $\begin{array}{l}\mathrm{N}=62 \\
\text { (lucid } \\
\text { dreamers) }\end{array}$ & $\begin{array}{l}\text { MILD, } \\
\text { reality } \\
\text { testing, } \\
\text { autosuggestio } \\
\text { n }\end{array}$ & $\begin{array}{l}\text { BL: } 20 \% \text { participants had LDs; } 0.21 \\
\text { participant/week. } \\
\text { MILD: } 26.3 \% ; 0.37 \text { p/w. } \\
\text { RT: } 29.1 \% ; 0.53 \text { p/w. } \\
\text { AS: } 19.5 \% ; 0.21 \mathrm{p} / \mathrm{w} .\end{array}$ & 8 (poor) \\
\hline 2 & Levitan, 1990a & $\begin{array}{l}\text { Field } \\
\text { (within) }\end{array}$ & $\begin{array}{l}2 \text { nap conditions: wake up } 2 \text { h } \\
\text { earlier and take a } 2 \text { h nap (a) } \\
\text { after } 2 \text { h or (b) after } 4 \text { h; } \\
\text { compared with the night before } \\
\text { naps. }\end{array}$ & $\begin{array}{l}\mathrm{N}=10 \\
\text { (lucid } \\
\text { dreamers) }\end{array}$ & $\begin{array}{l}\text { MILD, } \\
\text { WBTB }\end{array}$ & $\begin{array}{l}\text { Night before naps: } \sim 10 \% \text { of dreams were } \\
\text { lucid (9 in total). } \\
\text { Naps in total: } \sim 40 \% \text { (25) } \\
\text { Nap after } 2 \text { h: } \sim 50 \% \\
\text { Nap after } 4 \text { h: } \sim 33 \%\end{array}$ & 5 (poor) \\
\hline 3 & Levitan, 1990b & $\begin{array}{l}\text { Field } \\
\text { (within) }\end{array}$ & $\begin{array}{l}2 \text { conditions: } 15 \text { min MILD (a) } \\
\text { in the evening or (b) in the } \\
\text { morning }\end{array}$ & $\begin{array}{l}\mathrm{N}=20 \\
\text { (lucid } \\
\text { dreamers) }\end{array}$ & MILD & $\begin{array}{l}\text { Evening: 0.44 LDs/night (6 participants) } \\
\text { Morning: 0.26 LDs/night (3) }\end{array}$ & 5 (poor) \\
\hline 4 & Levitan, 1991a & $\begin{array}{l}\text { Field } \\
\text { (within) }\end{array}$ & $\begin{array}{l}3 \text { nights, } 3 \text { conditions: (a) wake } \\
\text { up } 90 \text { min earlier, } 90 \text { min } \\
\text { awake, MILD and } 90 \text { min nap; } \\
\text { (b) wake up } 90 \text { min earlier, } \\
\text { MILD and } 90 \text { min nap; (c) wake } \\
\text { up at normal time, MILD and } 90 \\
\text { min nap }\end{array}$ & $\begin{array}{l}\mathrm{N}=12 \\
\text { (lucid } \\
\text { dreamers) }\end{array}$ & $\begin{array}{l}\text { MILD, } \\
\text { WBTB }\end{array}$ & $\begin{array}{l}\text { a) } 9 \text { had LDs (75\%); } 8 \text { during the nap (67\%), } \\
1 \text { at night (8\%). } \\
\text { b): } 4 \text { had LDs (33\%); all } 4 \text { during the nap. } \\
\text { c): } 3 \text { had LDs (25\%); } 1 \text { during the nap (8\%), } \\
2 \text { at night (17\%). }\end{array}$ & 8 (poor) \\
\hline 5 & Levitan, 1991b & $\begin{array}{l}\text { Field } \\
\text { (within) }\end{array}$ & $\begin{array}{l}2 \text { conditions: after waking up } \\
\text { from a dream either (a) to count } \\
\text { or (b) to focus on the body }\end{array}$ & $\begin{array}{l}\mathrm{N}=30 \\
\text { (lucid } \\
\text { dreamers) }\end{array}$ & $\begin{array}{l}\text { WILD } \\
\text { (dream re- } \\
\text { entry) }\end{array}$ & $\begin{array}{l}43 \text { LDs out of } 191 \text { attempts (23\%); 66\% of } \\
\text { participants LDs following re-entry; 33\% of } \\
\text { all re-entered dreams were lucid. }\end{array}$ & 5 (poor) \\
\hline
\end{tabular}




\begin{tabular}{|c|c|c|c|c|c|c|c|}
\hline & & & image & & & & \\
\hline 6 & $\begin{array}{l}\text { Edelstein \& } \\
\text { LaBerge, } 1992\end{array}$ & $\begin{array}{l}\text { Field } \\
\text { (within) }\end{array}$ & $\begin{array}{l}2 \text { conditions were intended: (a) } \\
\text { wake up } 90 \text { min earlier, } 90 \text { min } \\
\text { awake, MILD and } 90 \text { min nap; } \\
\text { (b) go to bed } 90 \text { min later, wake } \\
\text { up at normal time, MILD and } 90 \\
\text { min nap. However, they were } \\
\text { not compared due to } \\
\text { methodological problems. } \\
\text { Compared instead naps with the } \\
\text { nights. }\end{array}$ & $\begin{array}{l}\mathrm{N}=18 \\
\text { (lucid } \\
\text { dreamers) }\end{array}$ & $\begin{array}{l}\text { MILD, } \\
\text { WBTB }\end{array}$ & $\begin{array}{l}11 \text { participants had LDs, } 9 \text { of them had more } \\
\text { LDs during the naps than the nights. } \\
8 \% \text { of the nights and } 37 \% \text { of the naps had } \\
\text { LDs. } 6 \% \text { of dreams reported from the nights } \\
\text { were lucid and } 20 \% \text { from the naps }\end{array}$ & 4 (poor) \\
\hline 7 & $\begin{array}{l}\text { Levitan, } \\
\text { LaBerge, \& } \\
\text { Dole, } 1992\end{array}$ & $\begin{array}{l}\text { Field } \\
\text { (within) }\end{array}$ & $\begin{array}{l}2 \text { conditions: (AM nap) wake up } \\
90 \text { min earlier, } 90 \text { min awake, } \\
\text { MILD and } 90 \text { min nap; (PM } \\
\text { nap) go to bed } 14-17 \text { hours after } \\
\text { a regular bedtime, MILD and } 90 \\
\text { min nap. }\end{array}$ & $\begin{array}{l}\mathrm{N}=22 \\
\text { (lucid } \\
\text { dreamers) }\end{array}$ & $\begin{array}{l}\text { MILD, } \\
\text { WBTB }\end{array}$ & $\begin{array}{l}32 \% \text { ( } 27 \text { in total) of nap dreams were lucid } \\
\text { ( } 42 \% \text { of AM and } 12 \% \text { of PM nap dreams), } \\
\text { while only } 4.1 \% \text { ( } 6 \text { out of } 145 \text { ) of night } \\
\text { dreams were lucid. } \\
12 \text { people ( } 55 \% \text { ) had LDs in naps, } 9 \text { had } \\
\text { more LDs in AM than PM. }\end{array}$ & 6 (poor) \\
\hline 8 & $\begin{array}{l}\text { Levitan \& } \\
\text { LaBerge, } 1994\end{array}$ & $\begin{array}{l}\text { Field } \\
\text { (within) }\end{array}$ & 28 days dream diary & $\begin{array}{l}\mathrm{N}=46 \\
\text { (lucid } \\
\text { dreamers; } \\
32 \mathrm{M} / 14 \mathrm{~F} \text { ) }\end{array}$ & $\begin{array}{l}\text { MILD, } \\
\text { reality } \\
\text { testing, } \\
\text { hypnotic } \\
\text { induction, } \\
\text { light stimulus }\end{array}$ & $\begin{array}{l}1228 \text { nights, } 2968 \text { logged dreams. } \\
262 \text { (8.8\%) of all dreams were lucid (from } \\
38 \text { participants). } \\
\text { Light stimulus device: } 3.7 \% \text { LDs; MILD: } \\
\text { 5.3\%; device + MILD: 8.6\%. }\end{array}$ & 6 (poor) \\
\hline 9 & $\begin{array}{l}\text { LaBerge, } \\
\text { Phillips, \& } \\
\text { Levitan, } 1994\end{array}$ & $\begin{array}{l}\text { Field } \\
\text { (within) }\end{array}$ & $\begin{array}{l}3 \text { conditions: (a) } 50 \text { min later to } \\
\text { bed, wake up } 10 \text { min earlier, } 10 \\
\text { min reading about LD, MILD } \\
\text { and } 90 \text { min nap; (b) } 30 \text { min later }\end{array}$ & $\begin{array}{l}\mathrm{N}=22 \\
\text { (lucid } \\
\text { dreamers; } \\
12 \mathrm{M} / 10 \mathrm{~F} \text { ) }\end{array}$ & $\begin{array}{l}\text { MILD, } \\
\text { WBTB }\end{array}$ & $\begin{array}{l}\text { Baseline (last } 6 \text { months): } 1 \text { LD in } 7 \text { nights. } \\
\text { Nap (a): } 1 \text { LD in } 11 \text { nights (5 LDs in total) } \\
\text { Nap (b): } 1 \text { LD in } 2 \text { nights ( } 20 \text { LDs) } \\
\text { Nap (c): } 1 \text { LD in } 1.6 \text { nights ( } 25 \text { LDs) }\end{array}$ & 6 (poor) \\
\hline
\end{tabular}




\begin{tabular}{|c|c|c|c|c|c|c|c|}
\hline & & & $\begin{array}{l}\text { to bed, wake up } 30 \text { min earlier, } \\
30 \text { min reading about LD, } \\
\text { MILD and } 90 \text { min nap; (c) } \\
\text { regular time to bed, wake up } 60 \\
\text { min earlier, } 60 \text { min reading } \\
\text { about LD, MILD and } 90 \text { min } \\
\text { nap }\end{array}$ & & & $\begin{array}{l}50 \text { out of } 189 \text { naps dreams (27\%) were lucid, } \\
\text { while only } 3 \text { out } 235 \text { night dreams (1.3\%) }\end{array}$ & \\
\hline 10 & $\begin{array}{l}\text { LaBerge \& } \\
\text { Levitan, } 1995\end{array}$ & $\begin{array}{l}\text { Field } \\
\text { (within) }\end{array}$ & $\begin{array}{l}\text { 4-24 nights (M=11), } 2 \\
\text { conditions: device producing } \\
\text { light cues (Q-ON) and } \\
\text { producing no light cues (Q- } \\
\text { OFF). Reports evaluated by } \\
\text { blinded judges. }\end{array}$ & $\begin{array}{l}\mathrm{N}=14 \\
\text { (lucid } \\
\text { dreamers; } \\
10 \mathrm{M} / 4 \mathrm{~F} \text { ) }\end{array}$ & $\begin{array}{l}\text { Light } \\
\text { stimulus }\end{array}$ & $\begin{array}{l}162 \text { reports ( } 81 \text { in each condition). } \\
32 \text { LDs in total: } 22 \text { (69\%) Q-ON and } 10 \\
\text { (31\%) Q-OFF. Mean rate (participant/night): } \\
\text { Q-ON 0.30 } \pm 0.24 \text {; Q-OFF } 0.09 \pm 0.15 \\
\text { ( }<<0.025 \text { ). } \\
6 \text { LDs ( } 5 \text { participants) were trigered by a cue } \\
\text { (6 in Q-ON, } 0.071 \pm 0.10 \text { vs. } 0 \text { in Q-OFF; } \\
\mathrm{p}<0.025 \text { ) } \\
8 \text { LDs (6 ps) were initiated by the Reality } \\
\text { Testing Button ( } 6 \text { in Q-ON, } 0.091 \pm 0.16 \text { vs. } 2 \\
\text { in Q-OFF, } 0.016 \pm 0.04 ; p<0.10 \text { ) } \\
18 \text { LDs (9 ps) had dreams triggered by any } \\
\text { occurrence of the device }(\mathrm{Q}-\mathrm{ON}, 0.174 \pm 0.21 \\
\text { vs. Q-OFF, } 0.04 \pm 0.09 ; \mathrm{p}<0.05 \text { ). }\end{array}$ & $\begin{array}{l}14 \\
\text { (moderate) }\end{array}$ \\
\hline 11 & $\begin{array}{l}\text { Purcell et al, } \\
1986\end{array}$ & $\begin{array}{l}\text { Field } \\
\text { (between) }\end{array}$ & $\begin{array}{l}3 \text { weeks; } 5 \text { groups: (1) Baseline } \\
\text { - dream reports only; (2) } \\
\text { Contrast -dream reports, weekly } \\
\text { group contact, report skills } \\
\text { questionaire [RSQ] and } \\
\text { motivated to make more }\end{array}$ & $\begin{array}{l}\mathrm{N}=48 \\
\text { (undergra } \\
\mathrm{d} \\
\text { students; } \\
\text { 22M/26F) }\end{array}$ & $\begin{array}{l}\text { Reflection, } \\
\text { reality } \\
\text { testing, post- } \\
\text { hypnotic } \\
\text { suggestion }\end{array}$ & $\begin{array}{l}\text { Baseline: } 0 \text { LDs } \\
\text { Contrast: } 1 \text { LD } \\
\text { Rossi: } 7 \text { LDs } \\
\text { Mnemonic: } 15 \text { LDs } \\
\text { Hypnosis: } 0 \text { LDs }\end{array}$ & $\begin{array}{l}13 \\
\text { (moderate) }\end{array}$ \\
\hline
\end{tabular}




\begin{tabular}{|c|c|c|c|c|c|c|c|}
\hline & & & $\begin{array}{l}\text { detailed reports; (3) Rossi - } \\
\text { dream reports, weekly group } \\
\text { contact, self-reflectiveness [SR] } \\
\text { and motivated to advance SR; } \\
\text { (4) Mnemonic - dream reports, } \\
\text { weekly group contact, RSQ, } \\
\text { reality testing and motivated to } \\
\text { LD; (5) Hypnosis - dream } \\
\text { reports, weekly individual } \\
\text { contact and post-hypnotic } \\
\text { suggestion (with individual } \\
\text { variations) }\end{array}$ & & & & \\
\hline 12 & $\begin{array}{l}\text { Zadra, Donderi, } \\
\text { \& Pihl, } 1992 \\
\text { Zadra, } 1991\end{array}$ & $\begin{array}{l}\text { Field } \\
\text { (between) }\end{array}$ & $\begin{array}{l}6 \text { weeks, } 3 \text { groups: No } \\
\text { Experience, No Technique } \\
\text { (NENT); No Experience, } \\
\text { Technique (NET); Experience, } \\
\text { Technique (ET) }\end{array}$ & $\begin{array}{l}\mathrm{N}=47 \\
\text { (universit } \\
\mathrm{y} \\
\text { students; } \\
17 \mathrm{M} / 30 \mathrm{~F} \text { ) }\end{array}$ & $\begin{array}{l}\text { Tholey's } \\
\text { combined } \\
\text { technique }\end{array}$ & $\begin{array}{l}\text { NENT: } 2 \text { LDs from } 2 \text { participants } \\
\text { (M=0.13[SD=0.35]); } 6 \text { PreLDs (0.40 [0.63]) } \\
\text { NET: } 23 \text { LDs from } 9 \text { ps (1.44 [1.93]); } 13 \\
\text { PreLDs ( } 0.81 \text { [0.75]) } \\
\text { ET: } 110 \text { LDs from all } 16 \text { ps (6.88 [6.62]); } 23 \\
\text { PreLDs (1.44 [1.32]) } \\
\text { Both access to the technique ( }<<0.05 \text { ) and } \\
\text { previous LD experience ( }<<0.02) \text { influenced } \\
\text { LD probability. } \\
\text { Lucidity: } 28 \% \text { spontaneously; } 44 \% \\
\text { observation of incongruities; } 23 \% \\
\text { nigtmares/anxiety dreams; } 5 \% \text { positive } \\
\text { emotions. }\end{array}$ & $\begin{array}{l}16 \\
\text { (moderate) }\end{array}$ \\
\hline 13 & $\begin{array}{l}\text { Schlag-Gies, } \\
1992\end{array}$ & $\begin{array}{l}\text { Field } \\
\text { (between) }\end{array}$ & $\begin{array}{l}8 \text { weeks; } 5 \text { groups: } \\
\text { Autosuggestion (A); Intention }\end{array}$ & $\begin{array}{l}\mathrm{N}=90 \\
(34 \mathrm{M} / 56 \mathrm{~F}\end{array}$ & $\begin{array}{l}\text { Autosuggesti } \\
\text { on, intention, }\end{array}$ & $\begin{array}{l}\text { A: original criteria - } 16 \text { LDs (2.3\%) / } \\
\text { conventional criteria - } 32 \text { LDs (4.6\%) }\end{array}$ & $\begin{array}{l}18 \\
\text { (moderate) }\end{array}$ \\
\hline
\end{tabular}




\begin{tabular}{|c|c|c|c|c|c|c|c|}
\hline & & & $\begin{array}{l}\text { (I); Reflection (R); Control } \\
\text { group without information about } \\
\text { LD (K); Control with } \\
\text { information about LD (X). More } \\
\text { strict criteria were used for } \\
\text { defining a dream as lucid (e.g. } \\
\text { involved some action taken as a } \\
\text { consequence of awareness of } \\
\text { dreaming) in comparison with } \\
\text { other studies. }\end{array}$ & ) & reflection & $\begin{array}{l}\text { I: } 11 \text { LDs (1.7\%) / } 31 \text { LDs (4.8\%) } \\
\text { R: } 32 \text { LDs (5.5\%) / } 79 \text { LDs (13.6\%) } \\
\text { K: } 0 \text { LDs (0\%) / } 2 \text { LDs (0.5\%) } \\
\text { X: } 3 \text { LDs (0.7\%) / } 18 \text { LDs (4.4\%) } \\
\text { There were more LDs in the technique } \\
\text { groups (A, I, R) than control groups } \\
(\mathrm{p}<.001) . \mathrm{R} \text { had more LDs than I ( }<.01) \\
\text { and A (p<.05) }\end{array}$ & \\
\hline 14 & $\begin{array}{l}\text { Spoormaker \& } \\
\text { van Den Bout, } \\
2006\end{array}$ & $\begin{array}{l}\text { Field } \\
\text { (between) }\end{array}$ & $\begin{array}{l}12 \text { weeks; } 3 \text { groups: (A) } 2 \text { hour } \\
\text { individual LD session; (B) } 2 \\
\text { hour group LD session; (C) } \\
\text { waiting list. LD used as a means } \\
\text { for nightmare treatment. }\end{array}$ & $\begin{array}{l}\mathrm{N}=23 \\
\text { (nightmar } \\
\text { e } \\
\text { sufferers; } \\
6 \mathrm{M} / 17 \mathrm{~W} \text { ) }\end{array}$ & Intention & $\begin{array}{l}\text { A: } 4 \text { participants became lucid and altered } \\
\text { nightmares } \\
\text { B: } 2 \text { participants } \\
\text { C: } 0\end{array}$ & $\begin{array}{l}11 \\
\text { (moderate) }\end{array}$ \\
\hline 15 & $\begin{array}{l}\text { Paulsson \& } \\
\text { Parker, } 2006\end{array}$ & $\begin{array}{l}\text { Field } \\
\text { (within) }\end{array}$ & $\begin{array}{l}2 \text { weeks (baseline }- \text { the week } \\
\text { before) }\end{array}$ & $\begin{array}{l}\mathrm{N}=20 \\
(11 \mathrm{M} / 9 \mathrm{~F})\end{array}$ & $\begin{array}{l}\text { Tholey's } \\
\text { combined } \\
\text { technique }\end{array}$ & $\begin{array}{l}\text { Baseline: LD frequency (nights/week): } \\
\mathrm{M}=0.13 \text { ( } \mathrm{SD}=0.22) \text {. } \\
1^{\text {st }} \text { week: } 11 \text { participants had LDs ( } 5 \text { who } \\
\text { never had before); LD frequency: } 0.90 \\
\text { (1.02). } \\
2^{\text {nd }} \text { week: } 9 \text { lucid participants; LD } \\
\text { frequency: } 1.25 \text { (1.86). } \\
\text { Technique significantly increased LD } \\
\text { frequency }(\mathrm{p}<0.05) \text {. }\end{array}$ & $\begin{array}{l}15 \\
\text { (moderate) }\end{array}$ \\
\hline 16 & $\begin{array}{l}\text { LaBerge et al, } \\
1981\end{array}$ & $\begin{array}{l}\text { Sleep lab } \\
\text { (within) }\end{array}$ & $\begin{array}{l}\text { 1-2 nights each; 5-10 min after } \\
\text { beginning of each REM period, } \\
\text { phrase „This is a dream“ was }\end{array}$ & $\mathrm{N}=4$ & $\begin{array}{l}\text { Acoustic } \\
\text { stimulus }\end{array}$ & $\begin{array}{l}15 \text { trials in total, lucidity in } 5 \text { (33\%) cases. } \\
\text { Incorporation with lucidity: } 3 \text { (20\%) } \\
\text { Incorporation without lucidity: } 2(13 \%)\end{array}$ & 5 (poor) \\
\hline
\end{tabular}




\begin{tabular}{|c|c|c|c|c|c|c|c|}
\hline & & & $\begin{array}{l}\text { played repeatedly with } \\
\text { increasing volume. }\end{array}$ & & & $\begin{array}{l}\text { Lucidity without incorporation: } 2 \text { (13\%) } \\
\text { Awakening without incorporation: } 8 \text { (53\%) }\end{array}$ & \\
\hline 17 & $\begin{array}{l}\text { LaBerge et al, } \\
1988 \\
\text { LaBerge, } 1987\end{array}$ & $\begin{array}{l}\text { Sleep lab } \\
\text { (within) }\end{array}$ & $\begin{array}{l}\text { 1-5 nights each (58 in total); } \\
\text { flashing light during REM sleep }\end{array}$ & $\mathrm{N}=44$ & $\begin{array}{l}\text { Light } \\
\text { stimulus }\end{array}$ & $\begin{array}{l}25 \text { participants ( } 55 \%) \text { had LDs } \\
50 \text { LDs in total: } 5 \text { (10\%) in REMPs before } \\
\text { the stimulus; } 11 \text { (22\%) in REMPs after the } \\
\text { stimulus, but not triggered by the stimulus; } \\
33 \text { (66\%) triggered by the stimulus; } 1 \text { LD } \\
\text { from NREM2. }\end{array}$ & 4 (poor) \\
\hline 18 & LaBerge, 1988 & $\begin{array}{l}\text { Field } \\
\text { (within) }\end{array}$ & $\begin{array}{l}8 \text { weekly group meetings; } \\
\text { participants had access to } \\
\text { DreamLight devices. }\end{array}$ & $\mathrm{N}=49$ & $\begin{array}{l}\text { Light } \\
\text { stimulus, } \\
\text { MILD, } \\
\text { reality testing }\end{array}$ & $\begin{array}{l}\text { Baseline: } 3.7 \% \text { of LDs } \\
\text { DreamLight without MILD: } 5.5 \% \text { LDs } \\
\text { MILD without DreamLight: } 13 \% \text { LDs } \\
\text { MILD with DreamLight: } 20 \% \text { LDs } \\
\text { DreamLight usage correlation with LDs: } \\
\text { r=0.098 } \pm 0.095 \text {, }<<0.022 \\
\text { MILD: } r=0.124 \pm 0.087, p<0.003 \\
\text { Reality testing: } r=0.036 \pm 0.102, p<0.24\end{array}$ & 5 (poor) \\
\hline 19 & Hearne, 1983 & $\begin{array}{l}\text { Sleep lab } \\
\text { (within) }\end{array}$ & $\begin{array}{l}1 \text { night each; } 4 \text { electric impulses } \\
\text { to the wrist during REM sleep; } \\
\text { one „catch trial“ (awakening } \\
\text { after no stimulation) }\end{array}$ & $\begin{array}{l}\mathrm{N}=12 \\
\text { (mostly } \\
\text { students; } \\
12 \mathrm{~F} \text { ) }\end{array}$ & $\begin{array}{l}\text { Electric } \\
\text { stimulus }\end{array}$ & $\begin{array}{l}6 \text { participants got lucid; } 2 \text { participants } \\
\text { became lucid but woke up at signalling; and } \\
1 \text { participant falsely perceived stimulation } \\
\text { and became lucid. }\end{array}$ & 9 (poor) \\
\hline 20 & $\begin{array}{l}\text { Dane, 1984; } \\
\text { Dane \& Van De } \\
\text { Castle, } 1984\end{array}$ & $\begin{array}{l}\text { Sleep lab } \\
\text { (between) }\end{array}$ & $\begin{array}{l}1 \text { night each; } 4 \text { conditions } \\
\text { (instructions have shifted during } \\
\text { the course of study - participants } \\
\text { were encouraged to signal even } \\
\text { if they were not sure whether } \\
\text { awake or dreaming [revised: } \\
\text { whether awake or sleeping]): }\end{array}$ & $\begin{array}{l}\mathrm{N}=30 \\
\text { (hypnotic } \\
\text { ally } \\
\text { susceptibl } \\
\text { e women; } \\
\text { 30F) }\end{array}$ & $\begin{array}{l}\text { Post-hypnotic } \\
\text { suggestion, } \\
\text { reflection }\end{array}$ & $\begin{array}{l}3 \text { types of LDs indentified: Unambiguous } \\
\text { REM LDs (UREMLDs); Ambiguous REM } \\
\text { LDs (AREMLDs); NREM LDs } \\
\text { (NREMLDs). } \\
\text { PHS + OWI: } 3 \text { UREMLDs (from } 3 \\
\text { participants); } 4 \text { AREMLDs (3); } 9 \\
\text { NREMLDs (4); } 7 \text { (of 8) participants in total. }\end{array}$ & $\begin{array}{l}15 \\
\text { (moderate) }\end{array}$ \\
\hline
\end{tabular}




\begin{tabular}{|c|c|c|c|c|c|c|c|}
\hline & & & $\begin{array}{l}\text { Posthypnotic Suggestion (PHS) } \\
\text { + Original Waking Instructions } \\
\text { (OWI); PHS + Revised Waking } \\
\text { Instructions (RWI); OWI only; } \\
\text { RWI only. PHS employed } \\
\text { personal symbols. }\end{array}$ & & & $\begin{array}{l}\text { PHS + RWI: } 2 \text { UREMLDs (2); } 3 \text { AREMLDs } \\
\text { (2); } 12 \text { NREMLDs (7); } 7 \text { (of 7) ps. } \\
\text { OWI: } 3 \text { NREMLDs (1); } 1 \text { (of 8) ps. } \\
\text { RWI: } 3 \text { UREMLDs (3); } 3 \text { AREMLDs (3); } 6 \\
\text { NREMLDs (5); } 6 \text { (of 7) ps. } \\
\text { All other conditions were significantly better } \\
\text { than OWI. }\end{array}$ & \\
\hline 21 & Reis, 1989 & $\begin{array}{l}\text { Field } \\
\text { (within) }\end{array}$ & $\begin{array}{l}\text { 1-4 nights each; varying } \\
\text { conditions (in some cases } \\
\text { individual training sessions } \\
\text { varied in kind, number and } \\
\text { length) }\end{array}$ & $\begin{array}{l}\mathrm{N}=8 \\
(4 \mathrm{M} / 4 \mathrm{~F})\end{array}$ & $\begin{array}{l}\text { Vibration, } \\
\text { acoustic } \\
\text { stimulus, } \\
\text { reflection }\end{array}$ & $\begin{array}{l}\text { Vibration + reflection (5 participants; } 13 \\
\text { nights): } 2 \text { LDs from } 2 \text { participants. } \\
\text { Vibration only (1 p; } 2 \text { n): } 0 \text { LDs } \\
\text { Sound only ( } 1 \text { p; } 1 \text { n): } 0 \text { LDs } \\
\text { Vibration + sound + reflection (1 p; } 3 \text { n): } 2 \\
\text { LDs. }\end{array}$ & 6 (poor) \\
\hline 22 & $\begin{array}{l}\text { Leslie \& } \\
\text { Ogilvie, } 1996\end{array}$ & $\begin{array}{l}\text { Sleep lab } \\
\text { (within) }\end{array}$ & $\begin{array}{l}2 \text { nights each sleeping in a } \\
\text { hammock; } 2 \text { counterbalanced } \\
\text { conditions: stationary hammock } \\
\text { (control); rocking hammock (at } \\
1 \mathrm{~Hz} \text { frequency for } 5 \text { min). } \\
\text { Reports from } 2^{\text {nd }}-4^{\text {th }} \text { REM } \\
\text { periods. Measures included self- } \\
\text { reflectiveness scale and } \\
\text { mentation continuum scale. }\end{array}$ & $\begin{array}{l}\mathrm{N}=7 \\
\text { (universit } \\
\mathrm{y} \\
\text { students) }\end{array}$ & $\begin{array}{l}\text { Vestibular } \\
\text { stimulation }\end{array}$ & $\begin{array}{l}45 \text { valid reports, subset of } 28 \text { REM periods } \\
\text { ( } 4 \text { per participant) used. } \\
\text { Peak self-reflectiveness (PSR): rocking in } \\
\text { early morning (M=4.90) and late morning } \\
\text { (4.62) vs. stationary early ( } 2.95 \text { ) and late } \\
(4.43) \text { ( }<<0.05) \text {. } \\
\text { Mentation continuum (MC): rocking early } \\
\text { (3.00) and late (1.91) vs. stationary early } \\
(1.05) \text { and late ( } 2.33)(\mathrm{p}<=0.05) \text {. } \\
\text { PSR and MC correlation } r=0.80 \text { ( }<<=0.001) \\
\text { Lucid: } 25 \% \text { ( } 6 \text { out of } 24) \text { of rocking dreams } \\
\text { vs. } 14 \% \text { ( } 3 \text { out of } 21) \text { of control dreams. }\end{array}$ & $\begin{array}{l}14 \\
\text { (moderate) }\end{array}$ \\
\hline 23 & Kueny, 1985 & $\begin{array}{l}\text { Sleep lab } \\
\text { (within/b }\end{array}$ & $\begin{array}{l}3 \text { weeks MILD training } \\
\text { program; } 4 \text { non consecutive }\end{array}$ & $\mathrm{N}=16$ & $\begin{array}{l}\text { Acoustic } \\
\text { stimulus, }\end{array}$ & $\begin{array}{l}\text { MILD only: } 6 \text { confirmed LDs from } 5 \\
\text { participants ( } 19 \text { reported LDs from } 5 \text { ps). }\end{array}$ & $\begin{array}{l}12 \\
\text { (moderate) }\end{array}$ \\
\hline
\end{tabular}




\begin{tabular}{|c|c|c|c|c|c|c|c|}
\hline & & etween) & $\begin{array}{l}\text { nights in a lab each: } 1^{\text {st }} \text { and } 2^{\text {nd }} \\
\text { nights: MILD only; } 3^{\text {rd }} \text { and } 4^{\text {th }} \\
\text { nights: MILD + acoustic } \\
\text { stimulus during REM. Acoustic } \\
\text { stimulus: (a) voice „Remember, } \\
\text { this is a dream“, } 5 \text { dB increase } \\
\text { every } 20 \text { s (Step-Voice); (b) } \\
\text { voice „Remember, this is a } \\
\text { dream“, } 4 \text { dB increase every } 4 \\
\text { min (Constant-Voice); (c) } \\
\text { musical tone, } 5 \text { dB increase } \\
\text { every } 20 \text { s (Step-Tone); (d) } \\
\text { musical tone, } 4 \text { dB increase } \\
\text { every } 4 \text { min (Constant-Tone). }\end{array}$ & & MILD & $\begin{array}{l}\text { MILD + acoustic stimulus: } 5 \text { from } 5 \text { ( } 22 \\
\text { from 9) } \\
\text { Step-Voice: } 3 \text { from } 3 \text { (12 from 4) } \\
\text { Constant-Voice: } 1 \text { (1) } \\
\text { Step-Tone: } 0 \text { ( } 5 \text { from } 4 \text { ) } \\
\text { Constant-Tone: } 1 \text { ( } 4 \text { from } 2 \text { ) } \\
\text { Trend (p<0.1) for Step condition to be more } \\
\text { effective than Constant. }\end{array}$ & \\
\hline 24 & $\begin{array}{l}\text { Ogilvie at al, } \\
1983\end{array}$ & $\begin{array}{l}\text { Sleep lab } \\
\text { (within) }\end{array}$ & $\begin{array}{l}\text { 1-4 nights in a lab; acoustic } \\
\text { stimulus (buzzer) after } 15 \text { min } \\
\text { of REM in the presence of } \\
\text { either high or low REM activity. } \\
\text { Participants were asked to } \\
\text { signal with their eyes after a } \\
\text { stimulus. Awakenings after eye } \\
\text { signalling or 30-60s after } \\
\text { stimulus. }\end{array}$ & $\begin{array}{l}\mathrm{N}=8 \\
\text { (lucid } \\
\text { dreamers) }\end{array}$ & $\begin{array}{l}\text { Acoustic } \\
\text { stimulus }\end{array}$ & $\begin{array}{l}\text { Total: 57\% lucid, 21\% prelucid, 22\% non- } \\
\text { lucid dreams } \\
\text { Spontaneous eye signaling ( } \mathrm{n}=14 \text { ): } 64 \% \\
\text { lucid, } 27 \% \text { prelucid, } 22 \% \text { nonlucid } \\
\text { Cued high ( } \mathrm{n}=16 \text { ): } 43 \% \text { lucid, } 21 \% \text { prelucid, } \\
36 \% \text { nonlucid. } \\
\text { Cued low ( }=15 \text { ): } 69 \% \text { lucid, } 12 \% \text { prelucid, } \\
36 \% \text { nonlucid }\end{array}$ & 2 (poor) \\
\hline 25 & $\begin{array}{l}\text { Spoormaker, } \\
\text { van den Bout, } \\
\text { \& Meijer, } 2003\end{array}$ & $\begin{array}{l}\text { Field } \\
\text { (within) }\end{array}$ & $\begin{array}{l}2 \text { months; LD used as a means } \\
\text { for nightmare treatment. }\end{array}$ & $\begin{array}{l}\mathrm{N}=8 \\
\text { (nightmar } \\
\mathrm{e}\end{array}$ & Intention & $\begin{array}{l}4 \text { participants became lucid, } 3 \text { of them were } \\
\text { able to alter the nightmare }\end{array}$ & 7 (poor) \\
\hline
\end{tabular}




\begin{tabular}{|c|c|c|c|c|c|c|c|}
\hline & & & & $\begin{array}{l}\text { sufferers; } \\
2 \mathrm{M} / 6 \mathrm{~F})\end{array}$ & & & \\
\hline 26 & \multirow[t]{2}{*}{ Galvin, 1993} & $\begin{array}{l}\text { Sleep lab } \\
\text { (within) }\end{array}$ & $\begin{array}{l}5 \text { nights (baseline }+4 \\
\text { experimental nights) in a lab } \\
\text { over } 9 \text { weeks. Posthypnotic } \\
\text { suggestion (PHS) was repeated } \\
\text { before each of experimental } \\
\text { nights. }\end{array}$ & \multirow[t]{2}{*}{$\begin{array}{l}\mathrm{N}=8 \\
\text { (nightmar } \\
\text { e } \\
\text { sufferers; } \\
\text { 2M/6F) }\end{array}$} & \multirow[t]{2}{*}{$\begin{array}{l}\text { Posthypnotic } \\
\text { suggestion }\end{array}$} & $\begin{array}{l}\text { Only } 1 \text { participants had verified LD in a } \\
\text { sleep lab on } 3 \text { occasions (REM/NREM2; } \\
\text { NREM2; unclear) }\end{array}$ & $\begin{array}{l}11 \\
\text { (moderate) }\end{array}$ \\
\hline 27 & & $\begin{array}{l}\text { Field } \\
\text { (within) }\end{array}$ & $\begin{array}{l}9 \text { weeks period; dream diary; } \\
\text { PHS delivered on weeks } 4,5,7 \text {, } \\
\& 8 \text { at the lab and the } \\
\text { participants were also given a } \\
\text { tape-recording for home use. }\end{array}$ & & & $\begin{array}{l}6 \text { out of } 8 \text { participants reported LDs in home } \\
\text { settings ( } 9 \text { LDs in total out of } 446 \text { dream } \\
\text { reports [ } 2 \%] \text { ); self-reflectiveness increased } \\
\text { over the time ( } p=.035) \text {. }\end{array}$ & $\begin{array}{l}14 \\
\text { (moderate) }\end{array}$ \\
\hline 28 & Malamud, 1979 & $\begin{array}{l}\text { Qualitativ } \\
\text { e }\end{array}$ & $\begin{array}{l}\text { Dialectical approach; about } 12 \\
\text { weeks period (varying) }\end{array}$ & $\begin{array}{l}\mathrm{N}=6 \\
(2 \mathrm{M} / 4 \mathrm{~F})\end{array}$ & Reflection & $\begin{array}{l}4 \text { participants had LDs during or shortly } \\
\text { after the training }\end{array}$ & 8 (poor) \\
\hline 29 & Purcell, 1988 & $\begin{array}{l}\text { Field } \\
\text { (between) }\end{array}$ & $\begin{array}{l}3 \text { weeks; } 3 \text { conditions: (1) } \\
\text { Baseline -dream reports only; } \\
\text { (2) Attention Control - dream } \\
\text { reports, report skills } \\
\text { questionnaire (RSQ), weekly } \\
\text { meeting; (3) Schema: the same } \\
\text { as (2) + dream control } \\
\text { questionnaire and a cue } \\
\text { (bracelet). Dream reports scored } \\
\text { by judges. }\end{array}$ & $\begin{array}{l}\mathrm{N}=94 \\
\text { (undergra } \\
\mathrm{d} \\
\text { students; } \\
49 \mathrm{M} / 46 \mathrm{~F} ; \\
54 \text { high } \\
\text { and } 41 \\
\text { low } \\
\text { dream } \\
\text { recallers) }\end{array}$ & Reflection & $\begin{array}{l}\text { Baseline: } 4 \text { (12.5\%) lucid participants, } 7 \\
\text { LDs out of } 433 \text { dreams (1.6\%) } \\
\text { Attention Control: } 3 \text { (10\%) lucids, } 3 \text { LDs out } \\
\text { of } 345 \text { ( } 0.9 \%) \\
\text { Schema [Reflection]: } 16 \text { (50\%) LDs, } 57 \text { LDs } \\
\text { out of } 434 \text { (13.1\%) } \\
\text { Number of lucid participants vs non-lucids - } \\
\text { significant differences across groups } \\
\text { (p<.001). Dream control training had } \\
\text { significant effect ( } p=.026)\end{array}$ & $\begin{array}{l}17 \\
\text { (moderate) }\end{array}$ \\
\hline
\end{tabular}




\begin{tabular}{|c|c|c|c|c|c|c|c|}
\hline 30 & Hickey, 1988 & $\begin{array}{l}\text { Sleep lab } \\
\text { (within) }\end{array}$ & $\begin{array}{l}4 \text { non consecutive nights in a } \\
\text { lab }\end{array}$ & $\begin{array}{l}\mathrm{N}=4 \\
\text { (children } \\
\text { aged 10- } \\
12 \text { ) }\end{array}$ & \multirow[t]{2}{*}{$\begin{array}{l}\text { MILD, } \\
\text { reflection, re- } \\
\text { dreaming and } \\
\text { other }\end{array}$} & $\begin{array}{l}2 \text { out of } 4 \text { children ( } 50 \% \text { ) had verified LDs } \\
\text { in a sleep lab; } 6 \text { LDs in } 16 \text { nights (38\%) }\end{array}$ & 7 (poor) \\
\hline 31 & & $\begin{array}{l}\text { Field } \\
\text { (within) }\end{array}$ & $\begin{array}{l}6 \text { weeks training program } \\
\text { (included also art activities) }\end{array}$ & $\begin{array}{l}\mathrm{N}=13 \\
\text { (children } \\
\text { aged 10- } \\
12 \text { ) }\end{array}$ & & $\begin{array}{l}12 \text { out of } 13 \text { children (92\%) had LDs ( } 24 \text { in } \\
\text { total) during the training programme }\end{array}$ & 7 (poor) \\
\hline 32 & $\begin{array}{l}\text { Ogilvie et al, } \\
1982\end{array}$ & $\begin{array}{l}\text { Sleep lab } \\
\text { (within/b } \\
\text { etween) }\end{array}$ & $\begin{array}{l}2 \text { nights in a lab; } 2 \text { groups: (1) } \\
\text { with alpha feedback training } \\
\text { (AFT); (2) without AFT. } \\
\text { Awakened } 4 \text { times during REM } \\
\text { sleep (twice with high alpha and } \\
\text { twice with low alpha). } 7 \text { point } \\
\text { lucidity and } 15 \text { point } \\
\text { lucidity/dream control scales } \\
\text { used. }\end{array}$ & $\begin{array}{l}\mathrm{N}=10 \\
\text { (lucid } \\
\text { dreamers; } \\
5 \mathrm{M} / 5 \mathrm{~F} \text { ) }\end{array}$ & $\begin{array}{l}\text { Alpha } \\
\text { feedback }\end{array}$ & $\begin{array}{l}\text { AFT had no effect on lucidity / REM alpha } \\
\text { levels; arousals from high alpha had higher } \\
\text { lucidity ratings than arousals from low } \\
\text { alpha. }\end{array}$ & $\begin{array}{l}11 \\
\text { (moderate) }\end{array}$ \\
\hline 33 & $\begin{array}{l}\text { Zadra \& Pihl, } \\
1997\end{array}$ & $\begin{array}{l}\text { Field } \\
\text { (within) }\end{array}$ & $\begin{array}{l}\text { Case series; } 2 \text { participants } \\
\text { (cases 1-2) had progressive } \\
\text { muscle relaxation, guided } \\
\text { imagery, and LD induction; } \\
\text { other } 3 \text { participants (cases 3-5) } \\
\text { LD induction alone (with some } \\
\text { guided imagery). }\end{array}$ & $\begin{array}{l}\mathrm{N}=5 \\
\text { (nightmar } \\
\mathrm{e} \\
\text { sufferers) }\end{array}$ & Intention & $\begin{array}{l}\text { Case 1: LD after } 4 \text { weeks } \\
\text { Cases 2-3: No LDs } \\
\text { Case 4: LD after } 1.5 \text { weeks } \\
\text { Case 5: LD after } 2.5 \text { (?) weeks }\end{array}$ & 5 (poor) \\
\hline 34 & Hearne, 1978 & $\begin{array}{l}\text { Sleep lab } \\
\text { (within) }\end{array}$ & $\begin{array}{l}1 \text { night in a lab (+adaptation } \\
\text { night before); } 2 \text { awakenings } \\
\text { during late REM periods: (1) }\end{array}$ & $\begin{array}{l}\mathrm{N}=10 \\
\text { (universit } \\
\mathrm{y}\end{array}$ & $\begin{array}{l}\text { Water } \\
\text { stimulus }\end{array}$ & $\begin{array}{l}\text { None of the participants had LDs. Water- } \\
\text { spray theme was present in } 6 \text { out of } 10 \\
\text { experimental reports, but not in } 10 \text { control }\end{array}$ & $\begin{array}{l}12 \\
\text { (moderate) }\end{array}$ \\
\hline
\end{tabular}




\begin{tabular}{|l|l|l|l|l|l|l|}
\hline & & & $\begin{array}{l}\text { experimental condition -after } \\
\text { splashing some water on their } \\
\text { face or hand with a syringe; (2) } \\
\text { control condition - only } \\
\text { standing with a syringe (without } \\
\text { splashing water). Dream reports } \\
\text { rated by judges. }\end{array}$ & $\begin{array}{l}\text { students; } \\
\text { 2M/8F) }\end{array}$ & & reports. \\
\hline 35 & LaBerge, 2004 & $\begin{array}{l}\text { Field } \\
\text { (within) }\end{array}$ & $\begin{array}{l}\text { 3 nights, 3 conditions: (1) } \\
\text { Placebo; (2) Donepezil 5mg; (3) } \\
\text { Donepezil 10mg. }\end{array}$ & $\begin{array}{l}\mathrm{N}=10 \\
(7 \mathrm{M} / 3 \mathrm{~F})\end{array}$ & $\begin{array}{l}\text { Donepezil } \\
\text { ingestion }\end{array}$ & $\begin{array}{l}\text { 9 of 10 reported LDs on Donepezil nights, } \\
\text { while 1 out of 10 only on control nights. } \\
\text { LD rates per night: 0.031 for placebo; 0.429 } \\
\text { for 5mg Donepezil; 0.754 for 10mg } \\
\text { Donepezil. 10mg Donepezil vs placebo } \\
\text { (p<.001). } \\
\text { Donepezil was also associated with an } \\
\text { increased sleep paralysis rate and 40\% } \\
\text { increase in estimated time awake. }\end{array}$ \\
\hline
\end{tabular}

Note: If more than one study reference is provided, the first in the list was the used as the primary one (e.g. for which methodological quality was assessed) 
Table 2. Methodological quality of the included studies (agreed ratings)

\begin{tabular}{|c|c|c|c|c|c|c|c|c|c|c|c|c|c|c|c|c|c|c|c|c|c|c|c|c|c|c|c|c|c|}
\hline \multirow{2}{*}{ No } & \multirow{2}{*}{ Reference } & \multicolumn{27}{|c|}{ Item number on the Downs \& Black's (1998) checklist } & \multirow{2}{*}{$\begin{array}{l}\text { Total } \\
\text { score }\end{array}$} \\
\hline & & 1 & 2 & 3 & 4 & 5 & 6 & 7 & 8 & 9 & 10 & 11 & 12 & 13 & 14 & 15 & 16 & 17 & 18 & 19 & 20 & 21 & 22 & 23 & 24 & 25 & 26 & 27 & \\
\hline 1 & Levitan, 1989 & 1 & 0 & 1 & 1 & 0 & 0 & 0 & 0 & 0 & 0 & 0 & 0 & 1 & 0 & 0 & 0 & 1 & 0 & 1 & 0 & 1 & 1 & 0 & 0 & 0 & 0 & 0 & 8 \\
\hline 2 & Levitan, 1990a & 1 & 0 & 0 & 1 & 0 & 0 & 0 & 0 & 0 & 0 & 0 & 0 & 1 & 0 & 0 & 0 & 0 & 0 & 0 & 0 & 1 & 1 & 0 & 0 & 0 & 0 & 0 & 5 \\
\hline 3 & Levitan, 1990b & 1 & 0 & 0 & 1 & 0 & 0 & 0 & 0 & 0 & 0 & 0 & 0 & 1 & 0 & 0 & 0 & 0 & 0 & 0 & 0 & 1 & 1 & 0 & 0 & 0 & 0 & 0 & 5 \\
\hline 4 & Levitan, 1991a & 1 & 0 & 0 & 1 & 0 & 1 & 0 & 0 & 0 & 0 & 0 & 0 & 1 & 0 & 0 & 1 & 1 & 0 & 0 & 0 & 1 & 1 & 0 & 0 & 0 & 0 & 0 & 8 \\
\hline 5 & Levitan, 1991b & 1 & 0 & 0 & 1 & 0 & 0 & 0 & 0 & 0 & 0 & 0 & 0 & 1 & 0 & 0 & 0 & 0 & 0 & 0 & 0 & 1 & 1 & 0 & 0 & 0 & 0 & 0 & 5 \\
\hline 6 & Edelstein \& LaBerge, 1992 & 0 & 0 & 0 & 1 & 0 & 0 & 0 & 0 & 0 & 0 & 0 & 0 & 1 & 0 & 0 & 0 & 0 & 0 & 0 & 0 & 1 & 1 & 0 & 0 & 0 & 0 & 0 & 4 \\
\hline 7 & Levitan, LaBerge \& Dole, 1992 & 1 & 0 & 0 & 1 & 0 & 0 & 0 & 0 & 0 & 0 & 0 & 0 & 1 & 0 & 0 & 0 & 0 & 0 & 1 & 0 & 1 & 1 & 0 & 0 & 0 & 0 & 0 & 6 \\
\hline 8 & Levitan \& LaBerge, 1994 & 1 & 0 & 1 & 0 & 0 & 0 & 0 & 0 & 0 & 0 & 0 & 0 & 1 & 0 & 0 & 0 & 0 & 0 & 1 & 0 & 1 & 1 & 0 & 0 & 0 & 0 & 0 & 6 \\
\hline 9 & LaBerge, Phillips \& Levitan, 1994 & 1 & 0 & 0 & 1 & 0 & 0 & 0 & 0 & 0 & 0 & 0 & 0 & 1 & 0 & 0 & 0 & 0 & 0 & 1 & 0 & 1 & 1 & 0 & 0 & 0 & 0 & 0 & 6 \\
\hline 10 & Levitan \& LaBerge, 1995 & 1 & 1 & 1 & 1 & 0 & 1 & 1 & 0 & 0 & 0 & 0 & 0 & 1 & 1 & 1 & 1 & 0 & 1 & 1 & 1 & 1 & 0 & 0 & 0 & 0 & 0 & 0 & 14 \\
\hline 11 & Purcell et al, 1986 & 0 & 0 & 1 & 1 & 0 & 1 & 1 & 0 & 1 & 1 & 0 & 0 & 1 & 0 & 0 & 0 & 1 & 1 & 0 & 1 & 1 & 1 & 1 & 0 & 0 & 0 & 0 & 13 \\
\hline 12 & Zadra, Donderi \& Pihl, 1992 & 1 & 1 & 1 & 1 & 1 & 1 & 1 & 0 & 1 & 0 & 0 & 0 & 1 & 0 & 1 & 0 & 1 & 1 & 0 & 1 & 1 & 1 & 0 & 0 & 0 & 1 & 0 & 16 \\
\hline 13 & Schlag-Gies, 1992 & 1 & 1 & 1 & 1 & 1 & 1 & 1 & 0 & 1 & 1 & 0 & 0 & 1 & 0 & 0 & 0 & 1 & 1 & 1 & 1 & 1 & 1 & 1 & 0 & 0 & 0 & 1 & 18 \\
\hline 14 & Spoormaker \& van den Bout, 2006 & 0 & 0 & 1 & 0 & 1 & 0 & 0 & 0 & 1 & 1 & 0 & 0 & 1 & 0 & 0 & 1 & 1 & 1 & 0 & 0 & 0 & 0 & 1 & 0 & 1 & 1 & 0 & 11 \\
\hline 15 & Paulsson \& Parker, 2006 & 1 & 1 & 1 & 1 & 1 & 1 & 1 & 0 & 1 & 0 & 0 & 0 & 1 & 0 & 0 & 1 & 1 & 1 & 0 & 0 & 1 & 1 & 0 & 0 & 0 & 0 & 1 & 15 \\
\hline 16 & LaBerge et al, 1981 & 1 & 0 & 0 & 0 & 0 & 1 & 0 & 0 & 1 & 0 & 0 & 0 & 0 & 0 & 0 & 0 & 0 & 0 & 1 & 1 & 0 & 0 & 0 & 0 & 0 & 0 & 0 & 5 \\
\hline 17 & LaBerge et al, 1988 & 1 & 0 & 0 & 0 & 0 & 1 & 0 & 0 & 0 & 0 & 0 & 0 & 0 & 0 & 0 & 0 & 0 & 0 & 1 & 1 & 0 & 0 & 0 & 0 & 0 & 0 & 0 & 4 \\
\hline 18 & LaBerge, 1988 & 0 & 0 & 0 & 0 & 0 & 0 & 1 & 0 & 0 & 1 & 0 & 0 & 1 & 0 & 0 & 0 & 0 & 0 & 0 & 0 & 1 & 1 & 0 & 0 & 0 & 0 & 0 & 5 \\
\hline 19 & Hearne, 1983 & 1 & 0 & 1 & 1 & 0 & 1 & 0 & 0 & 0 & 0 & 0 & 0 & 0 & 1 & 0 & 1 & 1 & 0 & 1 & 1 & 0 & 0 & 0 & 0 & 0 & 0 & 0 & 9 \\
\hline 20 & Dane, 1984 & 1 & 1 & 1 & 1 & 1 & 1 & 0 & 0 & 1 & 0 & 0 & 0 & 0 & 0 & 1 & 0 & 1 & 1 & 1 & 1 & 0 & 0 & 1 & 0 & 1 & 1 & 0 & 15 \\
\hline 21 & Reis, 1989 & 0 & 0 & 0 & 1 & 0 & 1 & 0 & 1 & 1 & 0 & 0 & 0 & 1 & 0 & 0 & 0 & 0 & 0 & 0 & 0 & 1 & 0 & 0 & 0 & 0 & 0 & 0 & 6 \\
\hline 22 & Leslie \& Ogilvie, 1996 & 1 & 1 & 0 & 1 & 1 & 1 & 0 & 0 & 1 & 1 & 0 & 0 & 0 & 1 & 1 & 0 & 1 & 1 & 1 & 1 & 0 & 0 & 0 & 0 & 0 & 1 & 0 & 14 \\
\hline
\end{tabular}




\begin{tabular}{|l|l|c|c|c|c|c|c|c|c|c|c|c|c|c|c|c|c|c|c|c|c|c|c|c|c|c|c|c|c|}
\hline 23 & Kueny, 1985 & 1 & 0 & 1 & 1 & 1 & 1 & 0 & 0 & 0 & 0 & 0 & 0 & 0 & 0 & 1 & 0 & 1 & 1 & 1 & 1 & 0 & 1 & 0 & 0 & 0 & 0 & 1 & $\mathbf{1 2}$ \\
\hline 24 & Ogilvie et al, 1983 & 0 & 0 & 0 & 0 & 0 & 0 & 0 & 0 & 0 & 0 & 0 & 0 & 0 & 0 & 0 & 0 & 0 & 0 & 1 & 1 & 0 & 0 & 0 & 0 & 0 & 0 & 0 & $\mathbf{2}$ \\
\hline 25 & $\begin{array}{l}\text { Spoormaker, van den Bout \& Meijer, } \\
\text { 2003 }\end{array}$ & 1 & 0 & 1 & 1 & 0 & 0 & 0 & 0 & 1 & 0 & 0 & 0 & 1 & 0 & 0 & 0 & 1 & 0 & 0 & 0 & 0 & 0 & 0 & 0 & 0 & 1 & 0 & $\mathbf{7}$ \\
\hline 26 & Galvin, 1993 (sleep lab) & 1 & 1 & 1 & 1 & 1 & 1 & 0 & 0 & 0 & 1 & 0 & 0 & 0 & 0 & 0 & 0 & 1 & 0 & 1 & 1 & 0 & 1 & 0 & 0 & 0 & 0 & 0 & $\mathbf{1 1}$ \\
\hline 27 & Galvin, 1993 (field) & 1 & 1 & 1 & 1 & 1 & 1 & 1 & 0 & 0 & 1 & 0 & 0 & 1 & 0 & 0 & 1 & 1 & 1 & 1 & 0 & 0 & 1 & 0 & 0 & 0 & 0 & 0 & $\mathbf{1 4}$ \\
\hline 28 & Malamud, 1979 & 1 & 1 & 1 & 1 & 1 & 0 & 0 & 0 & 1 & 0 & 0 & 0 & 1 & 0 & 0 & 0 & 0 & 0 & 0 & 0 & 0 & 1 & 0 & 0 & 0 & 0 & 0 & $\mathbf{8}$ \\
\hline 29 & Purcell, 1988 & 1 & 1 & 1 & 1 & 0 & 1 & 1 & 0 & 1 & 1 & 0 & 0 & 1 & 0 & 1 & 0 & 1 & 1 & 1 & 1 & 1 & 0 & 1 & 0 & 0 & 1 & 0 & $\mathbf{1 7}$ \\
\hline 30 & Hickey, 1988 (sleep lab) & 1 & 1 & 0 & 0 & 0 & 0 & 0 & 0 & 1 & 0 & 0 & 0 & 0 & 0 & 0 & 1 & 1 & 0 & 1 & 1 & 0 & 0 & 0 & 0 & 0 & 0 & 0 & $\mathbf{7}$ \\
\hline 31 & Hickey, 1988 (field) & 1 & 1 & 0 & 0 & 0 & 0 & 0 & 0 & 1 & 0 & 0 & 0 & 1 & 0 & 0 & 1 & 1 & 0 & 0 & 0 & 0 & 0 & 0 & 0 & 0 & 1 & 0 & $\mathbf{7}$ \\
\hline 32 & Ogilvie et al, 1982 & 0 & 0 & 1 & 1 & 0 & 0 & 0 & 0 & 1 & 0 & 0 & 0 & 0 & 1 & 1 & 0 & 1 & 1 & 1 & 1 & 0 & 1 & 0 & 0 & 0 & 1 & 0 & $\mathbf{1 1}$ \\
\hline 33 & Zadra \& Phil, 1997 & 0 & 0 & 1 & 1 & 0 & 0 & 0 & 0 & 1 & 0 & 0 & 0 & 1 & 0 & 0 & 0 & 0 & 0 & 0 & 0 & 0 & 0 & 0 & 0 & 0 & 1 & 0 & $\mathbf{5}$ \\
\hline 34 & Hearne, 1978 & 1 & 1 & 1 & 1 & 0 & 1 & 0 & 0 & 1 & 0 & 0 & 0 & 0 & 1 & 0 & 0 & 1 & 0 & 1 & 1 & 0 & 0 & 1 & 0 & 0 & 1 & 0 & $\mathbf{1 2}$ \\
\hline 35 & LaBerge, 2004 & 1 & 0 & 1 & 1 & 0 & 0 & 0 & 0 & 1 & 0 & 0 & 0 & 0 & 1 & 0 & 0 & 0 & 0 & 0 & 0 & 0 & 0 & 1 & 0 & 0 & 1 & 0 & $\mathbf{7}$ \\
\hline
\end{tabular}


Table 3. Empirically based Taxonomy of lucid dream induction techniques

\begin{tabular}{|c|c|c|}
\hline Method & $\begin{array}{l}\text { Effectiveness } \\
\text { evidence level }\end{array}$ & References \\
\hline \multicolumn{3}{|l|}{ 1. Cognitive techniques } \\
\hline 1.1. Dream-initiated (DILD) & & \\
\hline 1.1.1. MILD & Green & $\begin{array}{l}\text { Edelstein \& LaBerge, 1992; Kueny, 1985; LaBerge, 1988; LaBerge et al, } \\
\text { 1994; Levitan, 1989; 1990a; 1990b; 1991a; Levitan \& LaBerge, 1994; } \\
\text { Levitan et al, } 1992\end{array}$ \\
\hline 1.1.2. Reflection / reality testing & Green & $\begin{array}{l}\text { Dane, 1984; LaBerge, 1988; Levitan, 1989; Levitan \& LaBerge, 1994; } \\
\text { Malamud, 1979; Purcell, 1988; Purcell et al, 1986; Schlag-Gies, } 1992\end{array}$ \\
\hline 1.1.3. Intention & Green & $\begin{array}{l}\text { Schlag-Gies, 1992; Spoormaker et al, 2003; Spoormaker \& van den Bout, } \\
\text { 2006; Zadra \& Pihl, } 1997\end{array}$ \\
\hline 1.1.4. Autosuggestion & Yellow & Levitan, 1989; Schlag-Gies, 1992 \\
\hline 1.1.5. Tholey's combined technique & Green & Paulsson \& Parker, 2006; Zadra et al, 1992 \\
\hline 1.1.6. Post-hypnotic suggestion & Yellow & Dane, 1984; Galvin, 1993; Purcell et al, 1986 \\
\hline 1.1.7. Alpha feedback & Red & Ogilvie et al, 1982 \\
\hline
\end{tabular}




\begin{tabular}{|c|c|c|}
\hline 1.2. Wake-initiated (WILD) & & \\
\hline 1.2.1. Counting & Yellow & Levitan, 1991b \\
\hline 1.2.2. Body image & Yellow & Levitan, 1991b \\
\hline \multicolumn{3}{|l|}{ 2. External stimulation } \\
\hline 2.1. Light stimulus & Green & $\begin{array}{l}\text { LaBerge, 1988; LaBerge et al, 1988; LaBerge \& Levitan, 1995; Levitan \& } \\
\text { LaBerge, } 1994\end{array}$ \\
\hline 2.2. Acoustic stimulus & Yellow & Kueny, 1985; LaBerge et al, 1981; Ogilvie et al, 1983; Reis, 1989 \\
\hline 2.3. Vibro-tactile stimulus & Yellow & Reis, 1989 \\
\hline 2.4. Electro-tactile stimulus & Yellow & Hearne, 1983 \\
\hline 2.5. Vestibular stimulation & Yellow & Leslie \& Ogilvie, 1996 \\
\hline 2.6. Water stimulus & Red & Hearne, 1983 \\
\hline \multicolumn{3}{|l|}{ 3. Miscellaneous } \\
\hline \multicolumn{3}{|l|}{ 3.1. Drug application } \\
\hline 3.1.1. Donepezil & Yellow & LaBerge, 2004 \\
\hline 3.2. WBTB* & Green & $\begin{array}{l}\text { Edelstein \& LaBerge, 1992; LaBerge et al, 1994; Levitan, 1990a; 1991a; } \\
\text { Levitan et al, } 1992\end{array}$ \\
\hline
\end{tabular}


Note: Effectiveness evidence levels: Green - method was demonstrated to be successful in several empirical studies; Yellow - method showed some success but findings were not replicated or are ambiguous; Red - method was not successful. Reference lists include empirical studies in which these methods were empirically verified.. *WBTB technique was tested empirically only in combination with MILD. 